\title{
Dynamics of the Lake Michigan food web, 1970-2000
}

\author{
Charles P. Madenjian, Gary L. Fahnenstiel, Thomas H. Johengen, \\ Thomas F. Nalepa, Henry A. Vanderploeg, Guy W. Fleischer, \\ Philip J. Schneeberger, Darren M. Benjamin, Emily B. Smith, James R. Bence, \\ Edward S. Rutherford, Dennis S. Lavis, Dale M. Robertson, David J. Jude, and \\ Mark P. Ebener
}

\begin{abstract}
Herein, we document changes in the Lake Michigan food web between 1970 and 2000 and identify the factors responsible for these changes. Control of sea lamprey (Petromyzon marinus) and alewife (Alosa pseudoharengus) populations in Lake Michigan, beginning in the 1950s and 1960s, had profound effects on the food web. Recoveries of lake whitefish (Coregonus clupeaformis) and burbot (Lota lota) populations, as well as the buildup of salmonine populations, were attributable, at least in part, to sea lamprey control. Based on our analyses, predation by salmonines was primarily responsible for the reduction in alewife abundance during the 1970s and early 1980s. In turn, the decrease in alewife abundance likely contributed to recoveries of deepwater sculpin (Myoxocephalus thompsoni), yellow perch (Perca flavescens), and burbot populations during the 1970s and 1980s. Decrease in the abundance of all three dominant benthic macroinvertebrate groups, including Diporeia, oligochaetes, and sphaeriids, during the 1980s in nearshore waters ( $\leq 50 \mathrm{~m}$ deep) of Lake Michigan, was attributable to a decrease in primary production linked to a decline in phosphorus loadings. Continued decrease in Diporeia abundance during the 1990s was associated with the zebra mussel (Dreissena polymorpha) invasion, but specific mechanisms for zebra mussels affecting Diporeia abundance remain unidentified.
\end{abstract}

Résumé : On trouvera ici une étude des changements dans le réseau alimentaire du lac Michigan de 1970 à 2000 et des facteurs qui en sont responsables. Le contrôle des populations de la grande lamproie marine (Petromyzon marinus) et du gaspareau (Alosa pseudoharengus), qui a débuté dans les années 1950 et 1960, a eu un impact considérable sur le réseau alimentaire. Le rétablissement des populations du grand corégone (Coregonus clupeaformis) et de la lotte (Lota lota) et l'accroissement des populations de salmonidés sont dus, au moins en partie, au contrôle de la lamproie.

Received 22 March 2001. Accepted 25 January 2002. Published on the NRC Research Press Web site at http://cjfas.nrc.ca on 24 May 2002.

J16279

C.P. Madenjian ${ }^{1}$ and G.W. Fleischer. U.S. Geological Survey, Great Lakes Science Center, 1451 Green Road, Ann Arbor, MI 48105, U.S.A.

G.L. Fahnenstiel. National Oceanic and Atmospheric Administration, Great Lakes Environmental, Research Laboratory, Muskegon Field Station, 1431 Beach Street, Muskegon, MI 49441, U.S.A.

T.H. Johengen. Cooperative Institute for Limnology and Ecosystem Research, University of Michigan, 2200 Bonisteel Boulevard, Ann Arbor, MI 48109, U.S.A.

T.F. Nalepa and H.A. Vanderploeg. National Oceanic and Atmospheric Administration, Great Lakes Environmental, Research Laboratory, 2205 Commonwealth Boulevard, Ann Arbor, MI 48105, U.S.A.

P.J. Schneeberger. Michigan Department of Natural Resources, Marquette Fisheries Station, 484 Cherry Creek Road, Marquette, MI 49855, U.S.A.

D.M. Benjamin. Atlantic States Marine Fisheries Commission, 444 Eye Street, Washington, DC 20005, U.S.A.

E.B. Smith and J.R. Bence. Department of Fisheries and Wildlife, Michigan State University, East Lansing, MI 48824, U.S.A.

E.S. Rutherford. Institute for Fisheries Research, University of Michigan, Ann Arbor, MI 48109, U.S.A.

D.S. Lavis. U.S. Fish and Wildlife Service, Ludington Biological Station, 229 South Jebavy Drive, Ludington, MI 49431, U.S.A.

D.M. Robertson. U.S. Geological Survey, Water Resources Division, 8505 Research Way, Middleton, WI 53562, U.S.A.

D.J. Jude. Center for Great Lakes and Aquatic Sciences, University of Michigan, 501 East University, 717 Dennison Building, Ann Arbor, MI 48109, U.S.A.

M.P. Ebener. Inter-Tribal Fisheries and Assessment Program, Chippewa Ottawa Resource Authority, 179 West Three Mile Road, Sault Ste. Marie, MI 49783, U.S.A.

${ }^{1}$ Corresponding author (e-mail: chuck_madenjian@usgs.gov). 
D'après nos analyses, la réduction de la densité des gaspareaux dans les années 1970 et au début des années 1980 est due principalement à la prédation par les salmonidés. À son tour, la réduction des gaspareaux a sans doute contribué au rétablissement des populations du chabot de profondeur (Myoxocephalus thompsoni), de la perchaude (Perca flavescens) et de la lotte dans les années 1970 et 1980. Durant les années 1980, la décroissance de la densité des trois groupes dominants de macroinvertébrés benthiques, Diporeia, les oligochètes et les sphériidés, dans les eaux côtières ( $\leq 50 \mathrm{~m}$ de profondeur) du lac Michigan est attribuable à une diminution de la production primaire lié à une réduction des apports de phosphore. La poursuite du déclin des densités de Diporeia dans les années 1990 est associée à l'invasion de la moule zébrée (Dreissena polymorpha), bien que les mécanismes précis de l'effet des moules sur Diporeia n'aient pas encore été identifiés.

[Traduit par la Rédaction]

\section{Introduction}

The objective of the first symposium on Salmonid Communities in Oligotrophic Lakes (SCOL-1) was to identify the effects of the three major anthropogenic stressors of cultural eutrophication, fishery exploitation, and exotic species introductions on fish communities, especially salmonid communities, in the five Laurentian Great Lakes (Wells and McLain 1972, 1973). As part of the SCOL-1 effort, Wells and McLain (1973) examined the changes in Lake Michigan fish communities from 1880 to 1970 . One of the major conclusions from their study was that sea lamprey (Petromyzon marinus) and alewife (Alosa pseudoharengus) invasions between 1930 and 1950 more profoundly affected fish communities in Lake Michigan than either accelerated eutrophication or fishery exploitation. Nevertheless, Wells and McLain (1973) ascribed the population collapse of larger deepwater ciscoes, including Coregonus nigripinnis and Coregonus johannae, to overfishing. Wells and McLain (1973) did acknowledge that accelerated eutrophication and other pollution may have caused some changes in fish communities of Lake Michigan during 1880-1970; however, evidence to support this contention was not very strong. In retrospect, SCOL-1 was a milestone in that it marked the first attempt to explain changes in fish communities of the Laurentian Great Lakes during 1880-1970 in the context of anthropogenic stressors to the ecosystem.

The Lake Michigan food web has undergone tremendous changes since 1970. For example, alewife abundance declined substantially during the 1970s and early 1980s (Jude and Tesar 1985; Eck and Wells 1987). Bloater (Coregonus hoyi) abundance increased dramatically during the early 1980s, peaked in the late 1980s, and declined during the 1990s (Eck and Wells 1987; TeWinkel et al. 2002). Biomass of the salmonine population increased steadily from 1965 to 1986 (Stewart and Ibarra 1991). Phosphorus loadings to Lake Michigan decreased during the 1980s as a result of federally mandated water quality control measures (Johengen et al. 1994). The three major groups of benthic macroinvertebrates, namely the amphipod Diporeia, oligochaete worms (Oligochaeta), and fingernail clams (Sphaeriidae), decreased substantially in abundance in southern Lake Michigan at sites shallower than $50 \mathrm{~m}$ between 1980 and 1993 (Nalepa et al. 1998). The midsummer epilimnetic phytoplankton community in offshore waters (>40 m deep) shifted from a blue-green and green algae dominated community in the 1970 s to a phytoflagellate dominated community in the 1980s (Fahnenstiel and Scavia $1987 a$ ). The summer zooplankton community in offshore waters changed abruptly during the early 1980s from a community dominated by calanoid copepods to a community dominated by the large-bodied cladoceran Daphnia pulicaria (Evans and Jude 1986). The predatory cladoceran Bythotrephes cederstroemi, an invader from Eurasia, became established in Lake Michigan by 1986 (Lehman 1987). By 1993, the zebra mussel (Dreissena polymorpha), an invader from the Ponto-Caspian region, had colonized hard substrates within $7 \mathrm{~km}$ of shore between Waukegan and Michigan City (Nalepa et al. 1998). Presence of round goby (Neogobius melanostomus), a fish invader from the PontoCaspian region, was first documented in 1994 (Clapp et al. 2001).

Herein, we document dynamics of the Lake Michigan food web from 1970 through 2000, and then identify factors likely responsible for these ecosystem changes. As in SCOL-1, we address the potential effects of anthropogenic stressors on fish communities in Lake Michigan. Since the time of SCOL-1, the list of anthropogenic stressors to the Great Lakes ecosystems has been expanded to include contaminants and global climate change. We also re-examine conclusions from the SCOL-1 study, in light of the wealth of information on the Lake Michigan food web that has become available since 1970. As has been surmised from studies of other ecosystems (Likens 1989), we would expect that long-term observation and study are needed before we can begin to understand the dynamics of an ecosystem as large and complex as Lake Michigan. Therefore, we analyze the available long-term series of observations on phytoplankton, zooplankton, benthic macroinvertebrate, and fish communities in Lake Michigan to identify factors that may be responsible for changes that have occurred since 1970. Aquatic ecosystem structure can be regulated from the bottom up (McQueen et al. 1989), as well as from the top down (Kitchell and Carpenter 1993). How extensively have topdown and bottom-up effects pervaded the Lake Michigan food web? With this synthesis, we answer that question.

\section{Long-term trends in phosphorus loading and nutrient dynamics}

In Lake Michigan, phosphorus is the major nutrient that limits phytoplankton growth and has the greatest potential to adversely affect the lake's ecosystem (Schelske and Stoermer 1971; Schelske et al. 1974). Fortunately, phospho- 
Fig. 1. Annual estimates of total phosphorus loading to Lake Michigan, including Green Bay, for 1974-1991 and 1994-1995.

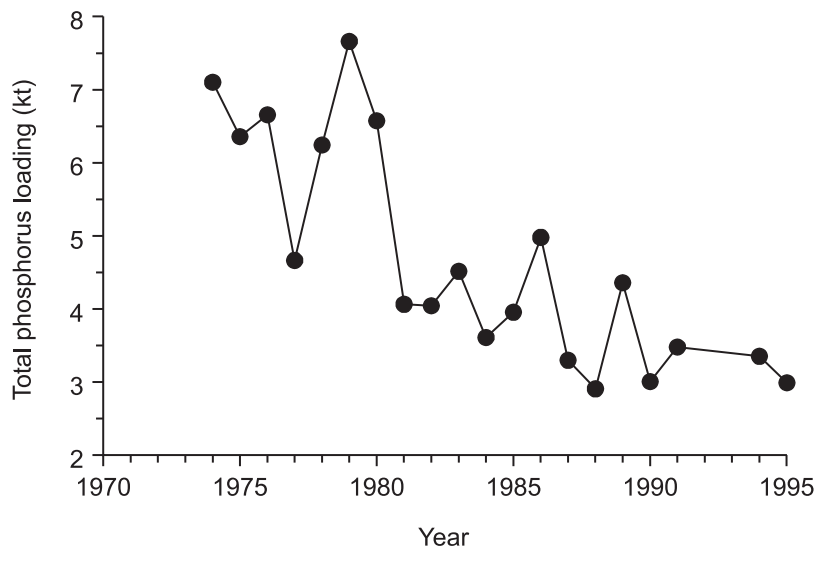

rus is also the easiest nutrient to control, primarily because phosphorus has no gaseous phase. Thus, regulation of phosphorus has been the primary management strategy for controlling eutrophication in the Great Lakes. Billions of dollars have been spent to reduce phosphorus inputs to the Great Lakes, and success has been documented in the lower Great Lakes (Johengen et al. 1994).

Phosphorus control programs substantially reduced phosphorus loadings to Lake Michigan (Fig. 1). Total annual loading decreased from over 6.5 kilotonnes (kt) in 1980 to about $4 \mathrm{kt}$ in 1981, coincident with control of most point sources from major water treatment plants and phosphorus bans on detergents. Loadings further decreased between 1981 and the late 1980s, before appearing to level off during the 1990s (Fig. 1). During 1994 and 1995, annual load estimates ranged from 3 to $3.5 \mathrm{kt}$.

Based on available data (Johengen et al. 1994; Makarewicz et al. 1998; T. Johengen, unpublished data), nitrate and silica concentrations in epilimnetic waters of Lake Michigan increased between 1976 and 1999. Increases were apparent for both spring maximum and summer minimum concentrations within the epilimnion. Increased nitrate levels have likely resulted from increased tributary loads, in response to human population growth and increases in industrial and agricultural activity (Vollenweider 1970), as well as from increased atmospheric loading, as was clearly demonstrated for Lake Superior (Bennet 1986). Silica concentrations would be expected to increase from an increase in anthropogenic loading, a decrease in the burial rate of silica to the sediment, or a decrease in rates with which dissolved silica is biologically utilized. Rate of use of silica by biota would decrease if species composition of the diatom community shifted toward smaller or less-silicified diatoms, or if there was an overall decrease in production rates of the diatom community.

\section{Dynamics of phytoplankton and primary production}

In toto, the evidence indicated that primary production in offshore waters of Lake Michigan trended neither upward nor downward during the last 25 years. Total phytoplankton abundance, measured as chlorophyll $a$ concentration, in off-
Fig. 2. (a) Average annual chlorophyll $a$ concentration and (b) average spring total phosphorus concentration (from March until water temperature reached $4^{\circ} \mathrm{C}$ ) in Lake Michigan at offshore (100-110 m) stations off Grand Haven $(\bullet)$ and Muskegon $(\nabla)$, Mich., 1976-1998. Also included are chlorophyll $a$ data for offshore Lake Michigan waters off Milwaukee, Wis., 1973-1974 (O) (Brooks and Torke 1977).
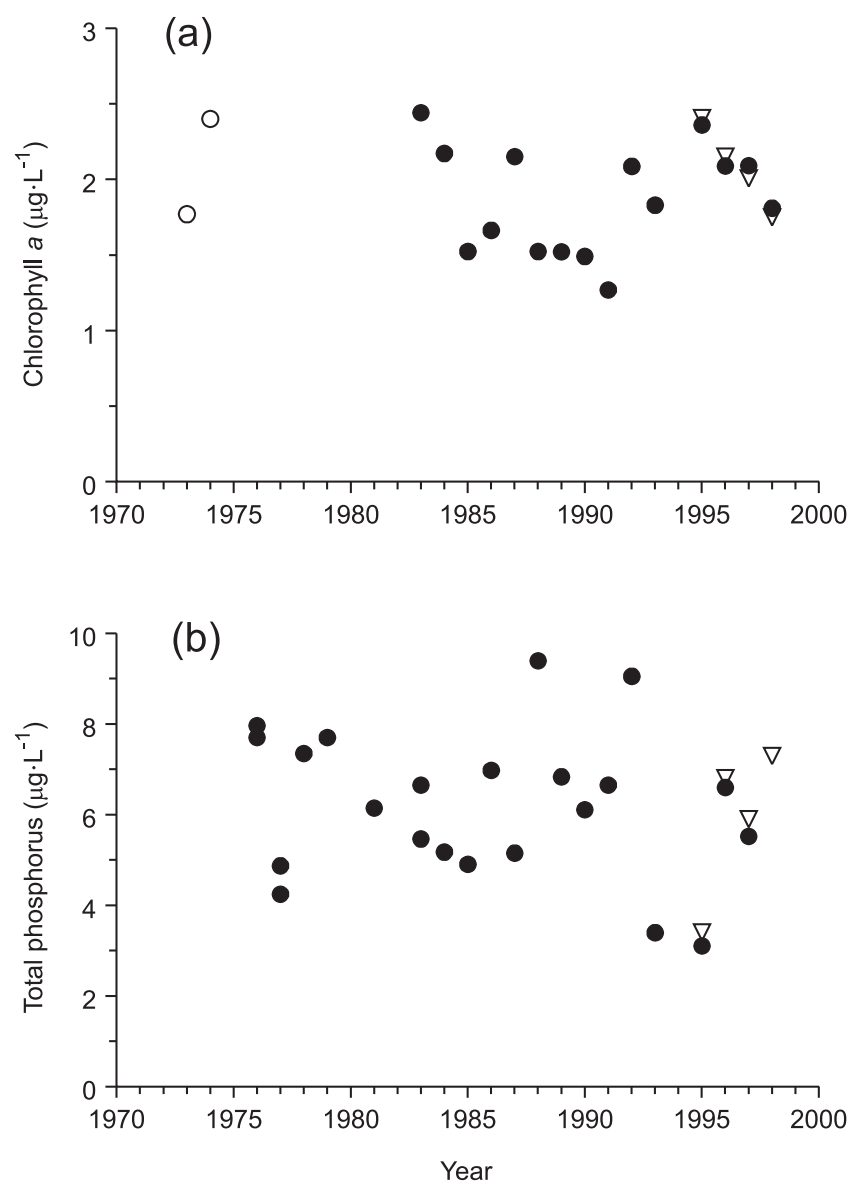

shore waters (>50 m deep) of Lake Michigan varied without trend during 1983-1998 (Fig. 2a), a finding corroborated by Fahnenstiel et al. (1998), who showed that phytoplankton abundance, measured as carbon, in offshore waters of Lake Michigan did not change between the 1986-1988 and 19931995 time periods. Addition of chlorophyll data from Brooks and Torke (1977) to the time series demonstrated no trends in offshore phytoplankton abundance since 1973 (Fig 2a). Similarly, total phosphorus concentration (TP) in the water column during spring, an indicator of primary production (Fahnenstiel et al. 1998), fluctuated about a constant level during 1976-1998 (Fig. 2b).

In contrast, species composition of the phytoplankton community in offshore waters of Lake Michigan underwent substantial changes in the past 30 years. Community structure during summer stratification shifted from one dominated by blue-green and green algae during the early 1970s to one dominated by phytoflagellates during the early 1980 s (Fahnenstiel and Scavia 1987a). Summertime dominance of phytoflagellates has continued into the 1990s (Makarewicz 
et al. 1998). Diatoms have composed the bulk of the phytoplankton community during the spring isothermal mixing period since 1970 .

In Lake Michigan, a deep chlorophyll layer typically forms in the upper hypolimnion and lower metalimnion during summer stratification, and this layer contributes between 5 and $10 \%$ of the annual total chlorophyll and annual primary production within the lake (Fahnenstiel and Scavia 1987b). Size of the deep chlorophyll layer increased between the 1970s and 1980s. This increase was attributed to greater light penetration caused by increased grazing due to increased abundance of the very largebodied zooplankter D. pulicaria (Scavia et al. 1986). This change in epilimnetic zooplankton composition did not persist for more than a few years (Evans 1992), and a shift back to smaller-bodied zooplankton apparently led to a reduction in the size and concentration of the deep chlorophyll layer (Fahnenstiel and Scavia 1987c; G. Fahnenstiel, unpublished data).

Although a long-term series of observations on phytoplankton abundance was not available for most of the 1970-2000 time period, the available data suggested that phytoplankton abundance and production in nearshore waters of Lake Michigan have decreased during the past 30 years. Schelske et al. (1980) intensively surveyed spring TP and chlorophyll $a$ concentrations in nearshore waters of the eastern side of the lake during 1972. Nearshore waters in the vicinity of the Cook Power Plant in the southeastern section of the lake was consistently sampled for chlorophyll $a$ concentration during 1973-1981. Similar sampling was conducted during the recent Episodic Events - Great Lakes Experiment (EEGLE) study from 1998-2000 in the same nearshore waters of Lake Michigan (G. Fahnenstiel, unpublished data). Comparison of data between the two time periods indicated that chlorophyll $a$ concentration decreased by more than $50 \%$ and spring TP decreased by $40 \%$ between the 1970s and the 1998-2000 time period. These declines in phytoplankton abundance and production were likely attributable to the reduction in phosphorus loading (Fig. 1).

Owing to lack of regular assessments of the species composition of the phytoplankton community in nearshore waters, changes in phytoplankton community structure were difficult to firmly establish. Diatoms were the predominant group during spring mixing in the 1990s (G. Fahnenstiel, unpublished data), just as they were in the 1970s (Chang and Rossman 1988). The springtime community was dominated by small centric diatoms (such as Stephanodiscus) in nearshore waters and by large centric diatoms (such as Aulacoseira) in offshore waters (Fahnenstiel and Scavia 1987a; G. Fahnenstiel, unpublished data). Relative abundance of blue-green algae during summer increased from the 1970 s to the 1980s in nearshore waters (Chang and Rossman 1988). Blue-green algae continued to be important in nearshore waters during summer stratification in the 1990 s (G. Fahnenstiel, unpublished data).

During the 1970s, silica may have limited the production of diatoms during the end of the spring diatom bloom in both nearshore and offshore waters of Lake Michigan (Schelske et al. 1986; Scavia and Fahnenstiel 1987).

\section{Dynamics of major benthic macroinvertebrate groups}

The three major benthic macroinvertebrate groups found in Lake Michigan have been the amphipod Diporeia, oligochaete worms (Oligochaeta), and fingernail clams (Sphaeriidae) (Nalepa et al. 1998). Benthic surveys conducted in the southern basin have been sufficiently consistent and thorough to construct a long-term record of abundances of these groups since 1965. Overall, abundances of Diporeia, oligochaetes, and sphaeriids increased between the 1960s and the early 1980s (Fig. 3). The magnitude of the increase varied with group and depth interval. Long-term trends in abundance during 1980-1993 differed between nearshore $(\leq 50 \mathrm{~m})$ and offshore $(>50 \mathrm{~m})$ depth zones of southern Lake Michigan (Nalepa et al. 1998, 2000a). In the nearshore, abundances of all three groups declined between 1980 and 1993 (Fig. 3a, 3b). In contrast, abundances of Diporeia, oligochaetes, and sphaeriids in the offshore zone exhibited no distinct trends over the same time period (Fig. $3 c, 3 d$ ). This difference in temporal trends of benthic macroinvertebrate abundances between nearshore and offshore zones may have been due to differences in temporal trends in phytoplankton abundance between the two zones. In large deep lakes like Lake Michigan, abundance of the dominant groups of benthic macroinvertebrates tends to be directly proportional to the amount of available food (Saether 1980). Increased phytoplankton abundance leads to increased amounts of organic material settling to the bottom region, thereby providing more potential food for macrobenthos. As noted above, phytoplankton abundance and primary production appeared to decrease in nearshore waters of Lake Michigan between the 1970s and 1990s, whereas no change was detected in offshore waters. The decrease in primary production in nearshore waters was probably due to the reduction in phosphorus loadings to the lake. Nutrient inputs from tributaries is better coupled with primary production in nearshore waters than in offshore waters (Schelske 1977). Finally, the zebra mussel invasion, in addition to the reduction in primary production, may have partly contributed to the decrease in Diporeia abundance in the nearshore region during the early 1990s (Nalepa et al. 2000a).

Continued decline of Diporeia in the nearshore region during the 1990s coincided with the invasion of Lake Michigan by the zebra mussel (Nalepa et al. 2000a, 2000b). By 1993, zebra mussels had colonized hard substrates within $7 \mathrm{~km}$ of shore between Waukegan and Michigan City. Zebra mussel density continued to increase at sites $<50 \mathrm{~m}$ deep in southern Lake Michigan between 1992 and 1999 (Nalepa et al. 2000a). Disappearance of Diporeia from several southern locations in waters shallower than $50 \mathrm{~m}$ was first observed in 1992, and this zone of disappearance spread northward by 1999 (T. Nalepa, unpublished data). The specific mechanism by which zebra mussels could have reduced Diporeia abundance remains unclear. If these drastic reductions in Diporeia density were to continue to spread throughout the lake, including deeper waters, the effects on the Lake Michigan food web may be substantial. Diporeia represents a major link between pelagic production and upper trophic levels 
Fig. 3. Average annual abundances of the dominant macroinvertebrate groups in the southern basin of Lake Michigan, in selected years over 1965-1993, within (a) the 16- to 30-m depth contour, (b) the 31- to 50-m depth contour, (c) the 51- to 80-m depth contour, and (d) the >80-m depth contour. Error bar represents one standard error for average total annual abundance. Solid bar represents Diporeia, open bar represents Sphaeriidae, and hatched bar represents Oligochaeta.

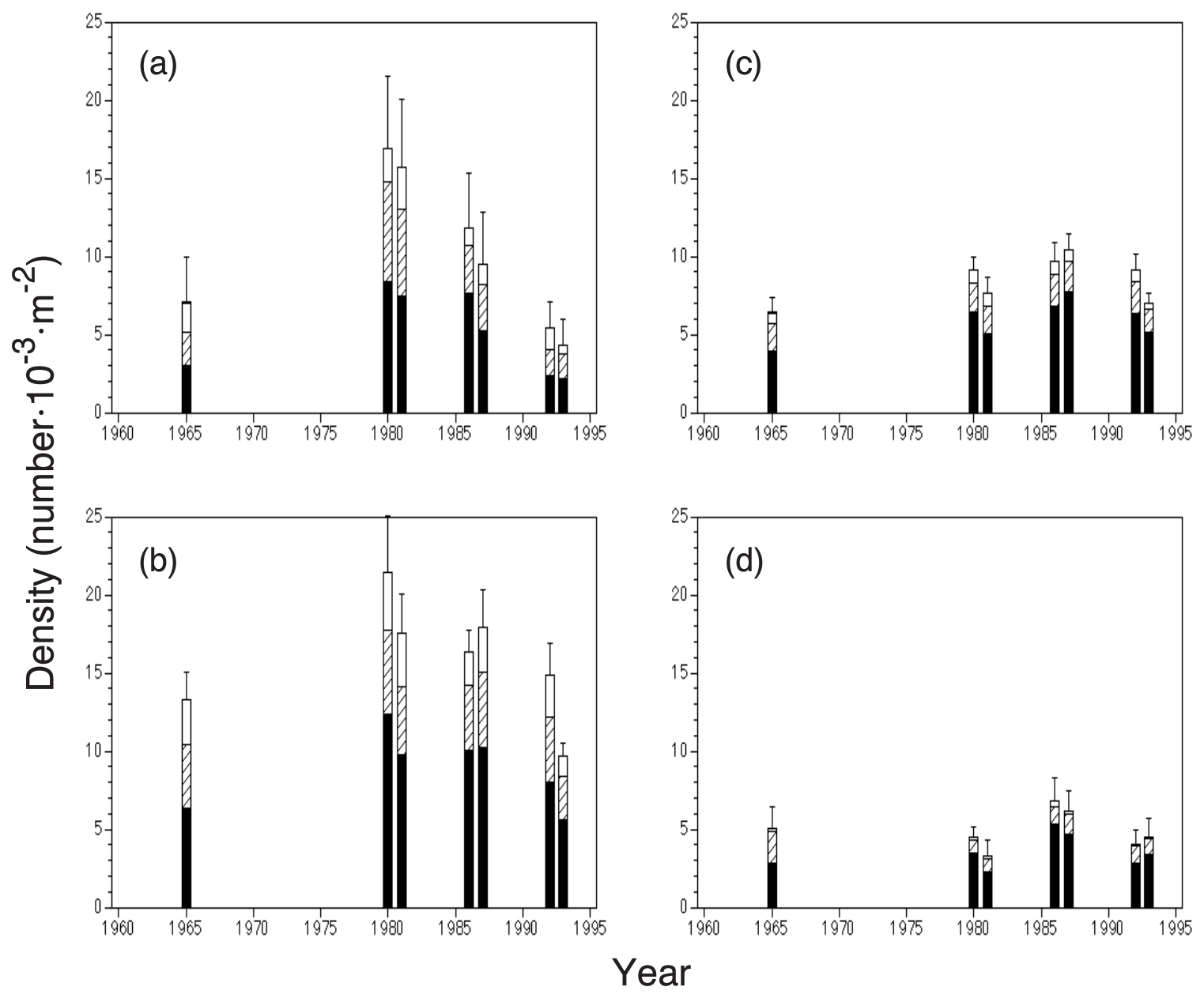

in Lake Michigan, and Diporeia exhibits a higher lipid content than other benthic macroinvertebrates (Gardner et al. 1985). If Diporeia were sufficiently reduced in abundance on a lake-wide basis, then fish heavily reliant on Diporeia as a food source would have to switch to other prey. Consequences of such diet switching on the growth and survival of these fishes remain unknown.

Although surveys by Nalepa (1987) and Nalepa et al. (1998) have documented changes in macroinvertebrate communities in areas deeper than $15 \mathrm{~m}$, community changes have also occurred in shallower regions of Lake Michigan. The zebra mussel invasion has resulted in increased abundance of chironomids and the amphipod Gammarus in the shallow, rocky habitats of southern Lake Michigan (Kuhns and Berg 1999).

\section{Dynamics of zooplankton}

Long-term trends in zooplankton community structure and abundance have been documented for nearshore waters ( $\leq 50 \mathrm{~m}$ deep) of southeastern Lake Michigan in the vicinity of the Cook Power Plant between 1972 and 1984 by Evans and Jude (1986) and Evans (1992), and for a large portion of the offshore region (>50 m deep) during 1983-1992 by Makarewicz et al. (1995). In deeper (30- to 40-m) waters sampled by Evans and Jude (1986), summer daphnid assemblage shifted from a 1972-1976 community strongly dominated by the medium-bodied Daphnia retrocurva to a 19771981 community strongly dominated by the large-bodied D. galeata mendotae, to a 1982-1984 community dominated by the very large-bodied $D$. pulicaria. In contrast, Daphnia retrocurva dominated the daphnid community in shallower waters in the Cook Plant vicinity from 1972 to 1984. Additionally, abundance of daphnids in shallower waters was substantially higher during 1972-1980 than during 19811984. Evans and Jude (1986) attributed this decrease in daphnid abundance to increased predation pressure exerted by the yellow perch (Perca flavescens) population, which increased dramatically in size between 1980 and 1984. Evans and Jude (1986) concluded that the appearance of the very large-bodied $D$. pulicaria in the deeper waters during 19821984 was possibly related to a decline in alewife abundance during the 1970s and early 1980s. Wells (1970) contended that increased alewife abundance in offshore waters of Lake 
Fig. 4. (a) Estimated lake-wide biomass of alewife (light shading), rainbow smelt (solid), deepwater sculpin (open), and bloater (dark shading) in Lake Michigan, 1973-1999. Estimates based on annual bottom trawl surveys performed by the USGS-GLSC. (b) Estimated lake-wide biomass of lake trout (light shading), brown trout (dark shading), rainbow trout (open), coho salmon (vertical bars), and chinook salmon (solid) in Lake Michigan, 1965-1998. Biomass was estimated using age-specific population models. See text for more details on modeling.

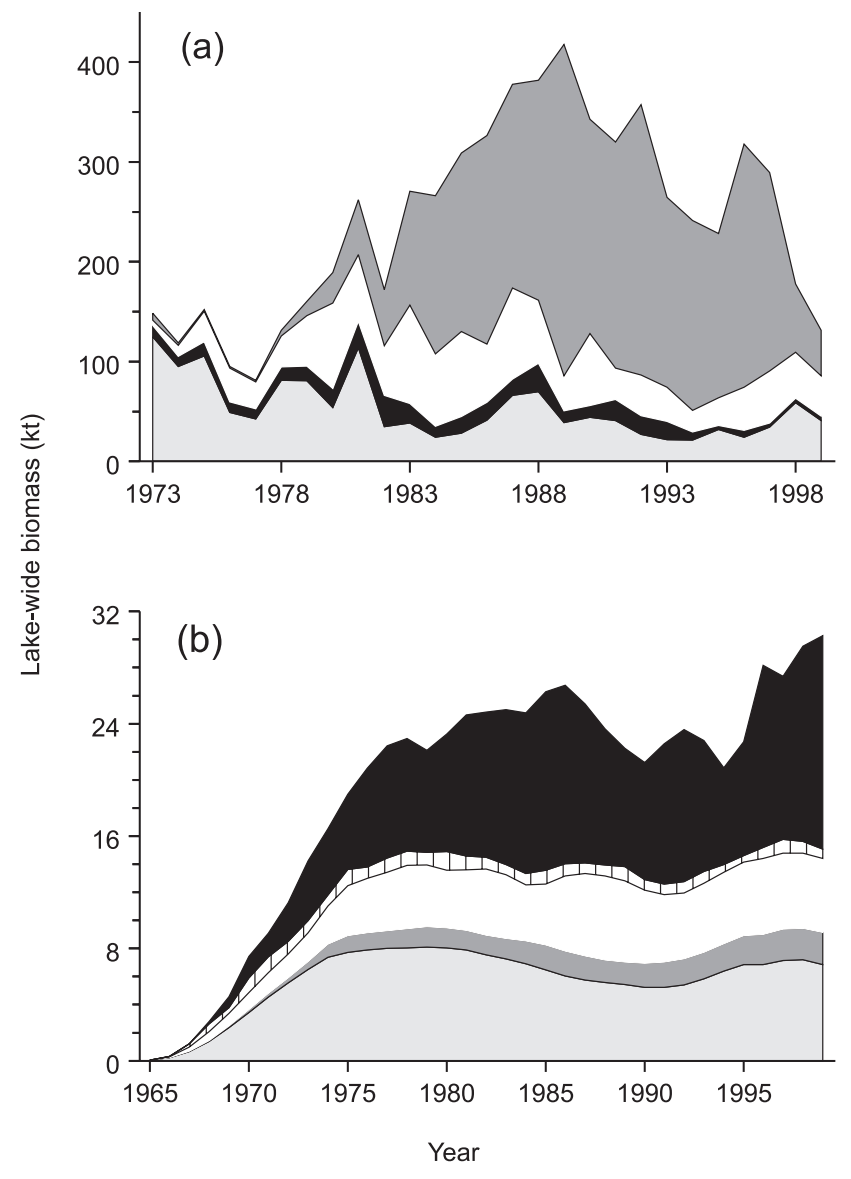

Michigan during the late 1950s and early 1960s led to a shift in the size structure of the summer zooplankton community from large-bodied to small-bodied copepods and cladocerans. Evidence to support the contention that high abundance of alewives in 1966 resulted in a zooplankton community dominated by small-bodied forms was compelling; however, relatively low alewife abundance did not necessarily imply that very large-bodied zooplankters would dominate the zooplankton community (Evans 1992).

Although species composition of the crustacean zooplankton community changed considerably during 1983-1992 in offshore waters of Lake Michigan, crustacean zooplankton biomass varied without trend during that time (Makarewicz et al. 1995). Furthermore, in comparing their data with observations by Scavia et al. (1986), Makarewicz et al. (1995) concluded that crustacean zooplankton biomass during the summer in offshore waters of Lake Michigan showed no trend between 1975 and 1992. Daphnia pulicaria was an important constituent of the daphnid community in 1983, but subsequently declined in abundance until nearly disappear- ing from the lake by 1987 (Makarewicz et al. 1995). Overall, Diaptomus dominated the zooplankton community during 1983-1992. Increases in rotifer biomass between 1983 and 1992 were correlated with increases in unicellular algae (Makarewicz et al. 1995). Based on correlation analysis, Makarewicz et al. (1995) suggested that alewives during 1983-1992 were probably not playing a dominant role in affecting zooplankton biomass and size structure except for the size structure of calanoid copepods. However, alewife abundance remained relatively low during this time period (Fig. 4). Preliminary examination of zooplankton samples during 1994-1999 suggested that no major changes in species composition or abundance had occurred since the Makarewicz et al. (1995) study (J. Cavaletto, NOAA Great Lakes Environmental Research Laboratory, Ann Arbor, MI 48105, U.S.A., personal communication).

Invasion of Lake Michigan by the predatory cladoceran Bythotrephes cederstroemi in 1986 appeared to have caused some changes in zooplankton community structure (Makarewicz et al. 1995). For example, the decrease in Daphnia retrocurva abundance after 1986 was most likely attributable to predation by Bythotrephes (Lehman and Cáceres 1993).

Other than the increase in rotifer biomass between 1983 and 1992, evidence for changes in zooplankton community structure and abundance originating from bottom-up effects was not strong (Makarewicz et al. 1995). Furthermore, the issue of whether changes in top-down control from alewives or from Bythotrephes led to changes in phytoplankton abundance or composition remains contentious (Evans 1992; Makarewicz et al. 1998).

Abundance of Mysis relicta, a common prey of alewife, bloater, rainbow smelt (Osmerus mordax), and lake whitefish (Coregonus clupeaformis), in southern Lake Michigan has remained relatively stable from the 1970s through 1998 (Pothoven et al. 2000). Mysis is an important predator of zooplankton in Lake Michigan. Whereas micrograzers (protozoans and ciliates) are an important component of the Lake Michigan food web (Fahnenstiel et al. 1998), insufficient data are available to characterize temporal trends in their abundance or their community structure.

\section{Dynamics of the prey fish community}

\section{Alewife}

The alewife invasion during the 1940s greatly altered the fish community of Lake Michigan. Declines in abundances of emerald shiner (Notropis atherinoides), deepwater sculpin (Myoxocephalus thompsoni), yellow perch, and bloater during the 1960s have been attributed to the alewife invasion (Wells and McLain 1973). Also, alewife predation on lake trout (Salvelinus namaycush) fry may represent a serious impediment to lake trout rehabilitation in the lower four Great Lakes (Krueger et al. 1995).

One of the reasons for launching a major stocking program for salmon and trout in Lake Michigan in 1965 was to reduce alewife abundance, which had reached nuisance levels during the 1960s (Hatch et al. 1981; Rutherford 1997). Alewives have dominated the diet of these stocked salmonines (Stewart and Ibarra 1991; Madenjian et al. 
1998a), and to a lesser extent, have also been eaten by burbot (Fratt et al. 1997).

Stocking of salmonines appeared to be effective in controlling alewife abundance. Alewife abundance decreased during the 1970s and early 1980s, coincident with the buildup of salmonines (Fig. 4). Alewife abundance has neither trended upward nor downward since the early 1980s, concomitant with relatively high levels of salmonine biomass within the lake. Lake-wide alewife biomass in 1973, based on bottom trawl surveys conducted by the U.S. Geological Survey (USGS) Great Lakes Science Center (GLSC), was estimated at $125 \mathrm{kt}$, whereas lake-wide biomass estimates averaged only 37 kt between 1984 and 1999 (Fig. 4a). Furthermore, additional GLSC trawling data indicated that the alewife decline was well underway by 1970 (Krause 1999). Although the lake-wide surveys of prey fish populations did not begin until 1973, GLSC bottom trawling was conducted at selected ports along the eastern and southern portions of the lake since 1962 (Hatch et al. 1981). Krause (1999), accounting for the reduced set of sampling locations during 1962-1972 by using a mixed model approach, estimated that lake-wide abundance of alewives in Lake Michigan was about twice as high in 1969 than it was in 1973. Further, the 1966 abundance was estimated at more than five times higher than the 1969 abundance. However, the decrease between 1966 and 1969 was partially attributable to a die-off occurring in 1967 (Brown 1972). Finally, Madenjian et al. (1986), using trend analysis, demonstrated a significant decline in alewife abundance in southeastern waters of Lake Michigan between 1973 and 1982.

Eck and Brown (1985) proposed that cold temperatures regulated alewife abundance in Lake Michigan, because a portion of the decline in alewife abundance during the 1970 s and early 1980s coincided with relatively cold weather. However, 1973-1999 data for alewife abundance and temperature do not support this contention. The alewife population did not rebound even though the cold years of 19771982 were followed by relatively warm years of 1983 and 1985-1992 (Fig. 4a; T. Karl, NOAA National Climatic Data Center, Asheville, NC 28801, U.S.A., unpublished data). Furthermore, annual alewife abundance during the 19731999 time period was poorly correlated $(r=-0.03, P=$ 0.8711, $n=27$ ) with heating degree days at Muskegon (Mich.), an indicator of winter severity (Eck and Brown 1985). In contrast, annual alewife abundance during the 1973-1998 time period showed a significant, negative relationship ( $r=-0.54, P=0.0058, n=26$ ) with estimated annual lake-wide consumption of alewives by salmonines.

The length-frequency distribution of Lake Michigan alewives did not drastically change between 1973 and 1999. Alewife growth rate and condition did not exhibit a trend between 1984 and 1995; however, alewife condition declined by about $15 \%$ after 1995 (C. Madenjian, unpublished data). Nearly all of the diet of adult alewives in Lake Michigan from 1970 to 1995 has been composed of zooplankton (chiefly cladocerans and copepods), Diporeia, and Mysis (Davis et al. 1997). Lipid content in alewives neither increased nor decreased between 1969 and 1995 (Madenjian et al. 2000), and modal length of adult alewives in bottom trawls has shown no trend since 1973 (C. Madenjian, unpub-
Fig. 5. Abundance of (a) adult (>120 mm total length) and (b) age-0 bloaters in Lake Michigan, 1973-1999, based on annual bottom trawl surveys performed by the USGS-GLSC. Catch per unit of effort (CPUE) expressed in number of fish caught per 10-min bottom trawl tow. Horizontal line represents mean catch rate for entire time period.

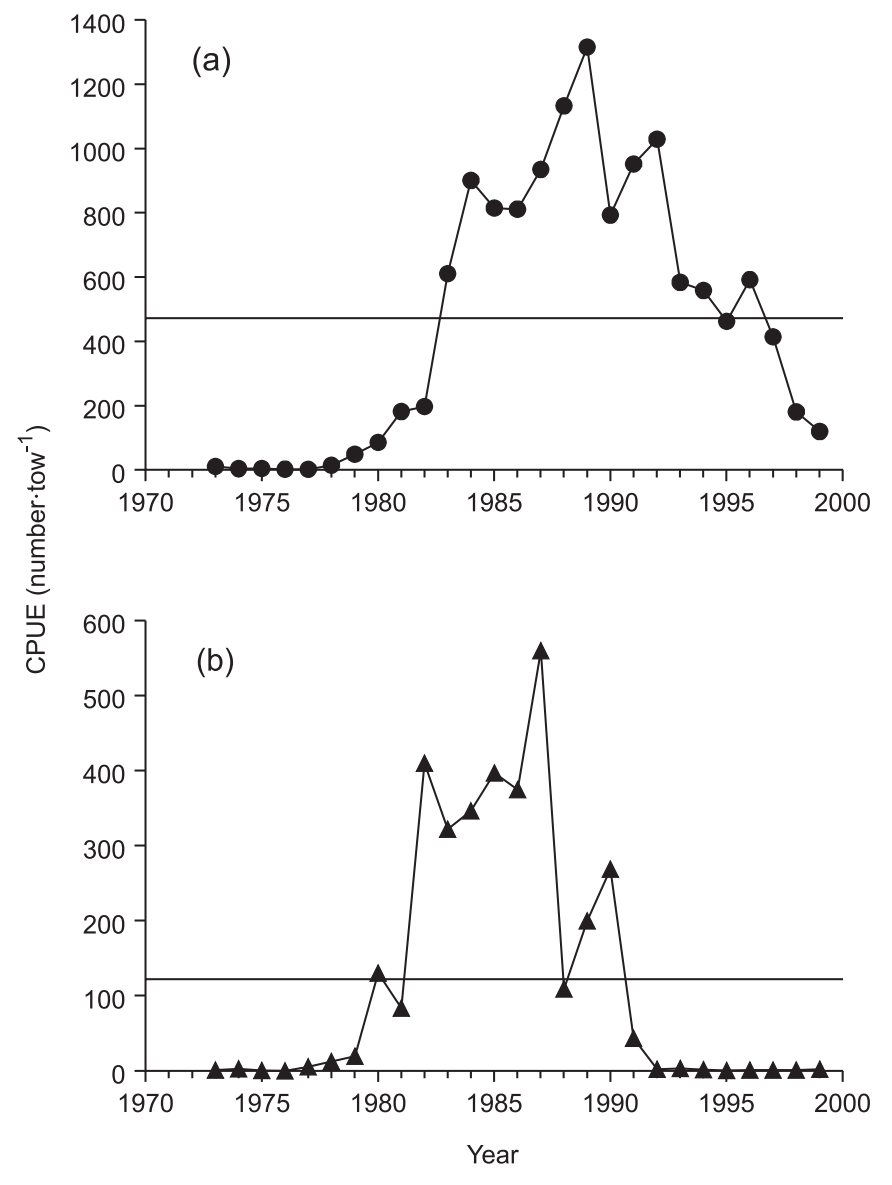

lished data). The recent decline in alewife condition may be linked to the recent decline in Diporeia abundance.

\section{Bloater}

Abundance of age-1 and older (hereafter referred to as adult) bloater in Lake Michigan has undergone dramatic changes in the last 30 years (Fig. 5a). Bloater recruitment started to increase in 1977, and relatively large year-classes were produced during 1980-1990 (Fig. 5b). Since 1992, however, year-class strength has been very weak. Temporal trends in abundance of adult bloater corresponded well with temporal trends in age-0 abundance. Adult abundance increased exponentially during 1977-1983 and then continued to increase, albeit at a slower rate, until 1989 (Fig. 5a). Since peaking in 1989, adult abundance has decreased. Examination of bottom trawl data for years 1962-1972, when spatial coverage of the lake during fall surveys was incomplete, suggested that adult bloater abundance had also peaked sometime during the late 1950s or early 1960s (G. Fleischer, unpublished data).

Reasons for rise and fall in bloater abundance between 1970 and 2000 were not clear. Decline in bloater abundance during the 1960s was attributed to alewives interfering with 
bloater reproduction (Wells and McLain 1973). However, alewife abundance was relatively low during 1992-1999, when bloater year-class strength was very low. Jude and Tesar (1985) proposed that release from commercial exploitation, more than release from alewife interference, stimulated bloater recovery beginning in the late 1970s. However, exploitation rate on bloaters during the late 1980s and early 1990 s was only about $1 \%$ per year, yet bloater abundance has been declining since 1989 . We propose a new hypothesis to explain the pattern in bloater abundance in Lake Michigan for the past 40 years: bloater abundance in Lake Michigan follows a cycle with a period of about 30 years. Further, the cycle appears to be mainly independent of interactions with other fish populations or humans, and some type of density-dependent feedback may be involved in maintaining these cycles.

Growth and lipid content of bloaters in Lake Michigan have varied with population size, whereas diet composition has been consistent. As abundance increased during the 1980 s, both growth rate and lipid content decreased (Madenjian et al. 2000; TeWinkel et al. 2002). Diporeia and Mysis have remained the mainstay of adult bloater diet in Lake Michigan (Davis et al. 1997). Sex ratio of the bloater population became skewed, with females predominating, during the late 1980s (TeWinkel et al. 2002).

\section{Rainbow smelt}

Rainbow smelt became established in Lake Michigan by 1936 (Wells and McLain 1972, 1973). This naturalized population of rainbow smelt continues to be exploited by commercial fisheries, albeit at lesser yields compared with bloater (S. Nelson, USGS Great Lakes Science Center COMCAT database, Ann Arbor, MI 48105, U.S.A.). Adult rainbow smelt have remained an important diet constituent for intermediate-sized (400- to 600-mm total length) lake trout in nearshore waters of Lake Michigan since the 1970s (Madenjian et al. 1998a). Also, rainbow smelt represented an important diet component for salmon during 1983-1987 (Stewart and Ibarra 1991).

While relatively low during 1973-1977, lake-wide biomass (as estimated via bottom trawling) of rainbow smelt increased during 1977-1982 (Fig. 4a). On average, lake-wide biomass of rainbow smelt was relatively high during 19821992, but then declined between 1992 and 1997. Reasons for the decline were not obvious. It seems unlikely that predation on rainbow smelt by salmonines has increased substantially since 1987 (see section on Dynamics of the salmonine community).

Mean total length of adult rainbow smelt in Lake Michigan decreased approximately $10 \%$ from 1973 to 1987 , with no appreciable decrease since 1987 (G. Fleischer, unpublished data). The decrease in rainbow smelt size was most likely attributable to an increase in predation due to buildup of salmonine biomass. Lipid content of rainbow smelt did not exhibit any definitive trend from the early 1970s to 1995 (Madenjian et al. 2000). Diet of adult rainbow smelt in Lake Michigan has consisted primarily of Mysis and small fish, especially young-of-the-year (YOY) alewife, during both the 1970s and 1994-1995 (Davis et al. 1997).
Fig. 6. Abundance of slimy $(\bullet)$ and deepwater $(\nabla)$ sculpins in Lake Michigan, 1973-1999, based on annual bottom trawl surveys performed by the USGS-GLSC. Catch per unit of effort (CPUE) expressed in $(a)$ number and $(b)$ kilograms of fish caught per 10-min bottom trawl tow.
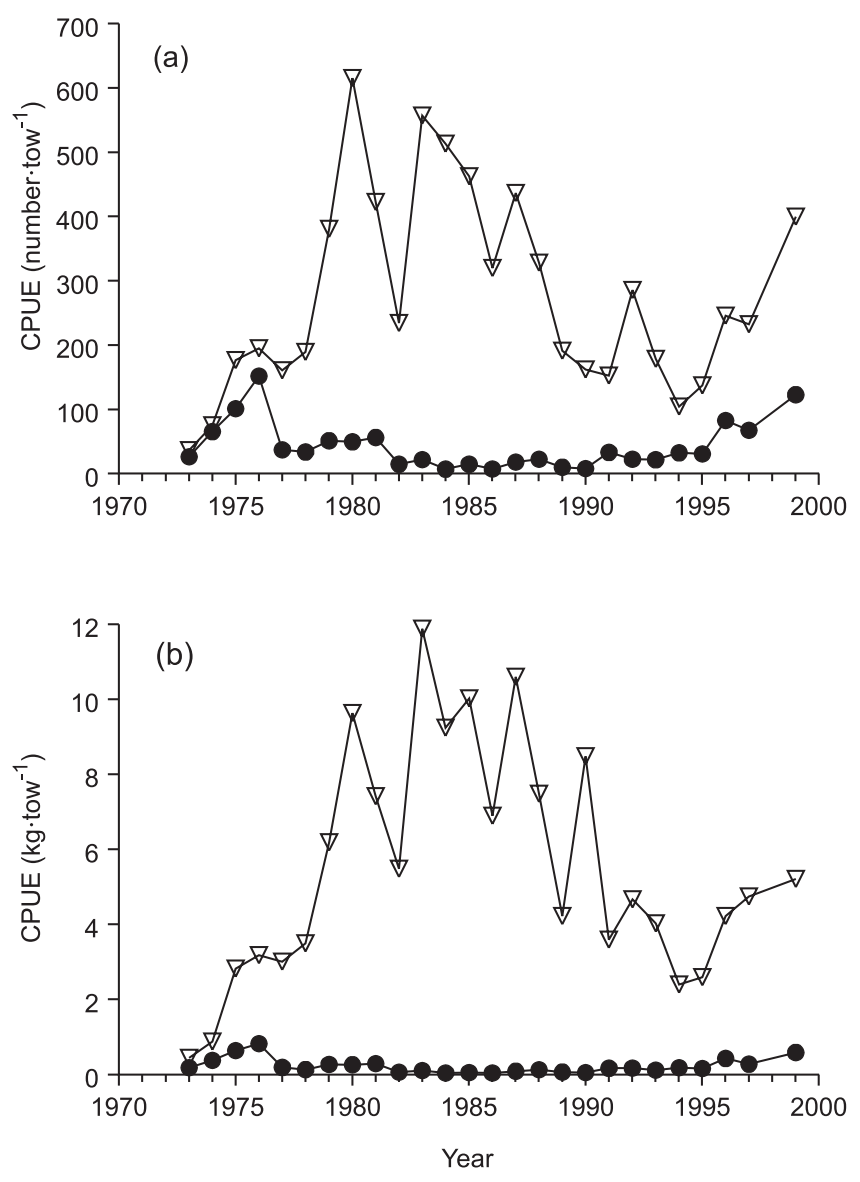

\section{Deepwater sculpin}

A substantial portion of the diet of burbot in Lake Michigan is composed of deepwater sculpins (Fratt et al. 1997). To a lesser degree, deepwater sculpins are also eaten by lake trout (Madenjian et al. 1998a). Abundance of deepwater sculpin in Lake Michigan increased rapidly between 1973 and 1983 (Fig. 6). After peaking in the early 1980s, deepwater sculpin lake-wide biomass declined until 1991, but showed no further decline after 1991 (Fig. 4a). Rapid increase in population size during 1973-1983 was most likely attributable to the decrease in alewife abundance during that time; Wells and McLain $(1972,1973)$ proposed that the decline in deepwater sculpin abundance during the 1960s was due to interference, by alewives, with deepwater sculpin recruitment. Alewives may consume the pelagic fry of deepwater sculpins. The decrease in deepwater sculpin abundance between the early 1980s and 1991 was probably due to increased predation by the recovering burbot population, which increased in size during the 1980s but appeared to level off in size during the 1990s (Fig. 7). Diporeia has dominated deepwater sculpin diet in Lake Michigan during 1970-1995 (Davis et al. 1997). 
Fig. 7. Abundance of burbot in Lake Michigan, 1973-1999, based on annual bottom trawl surveys performed by the USGSGLSC. Catch per unit of effort (CPUE) expressed in number of fish caught per 10-min bottom trawl tow.

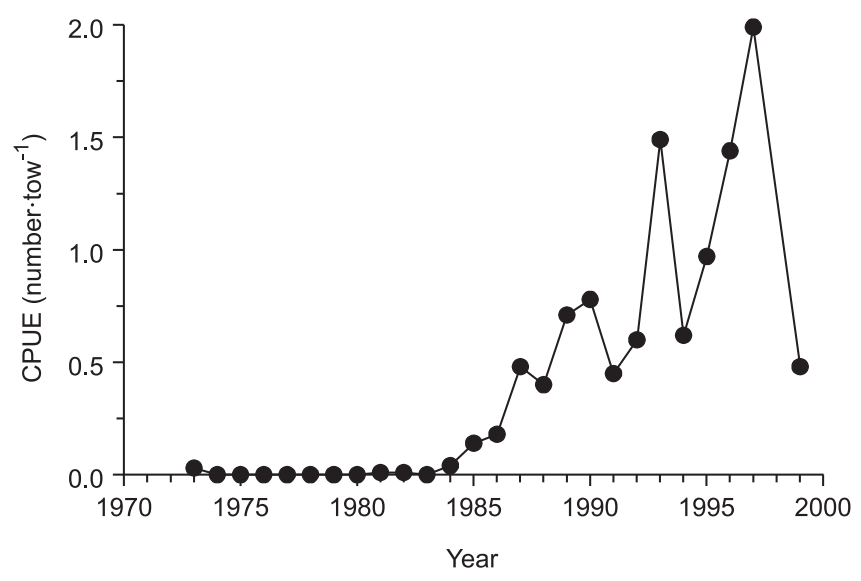

\section{Slimy sculpin}

Slimy sculpin (Cottus cognatus) has typically been preyed upon by juvenile lake trout in Lake Michigan, at least since the 1970s (Madenjian et al. 1998a). To a lesser degree, slimy sculpins are also eaten by burbot (Fratt et al. 1997). Longterm trends in slimy sculpin abundance, as determined by bottom trawl surveys, appeared to be related to changes in the spatial distribution of newly stocked lake trout. Slimy sculpin abundance decreased during the 1970s and early 1980 s, remained relatively low during most of the 1980 s, and then increased during the 1990s (Fig. 6). Prior to 1986, most of the lake trout stocking in Lake Michigan occurred relatively close to shore, but stocking emphasis was placed on offshore refuge areas beginning in 1986 (Holey et al. 1995). An increase in predation on slimy sculpins with increased lake trout population size during the 1970s probably caused the decrease in slimy sculpin abundance during the 1970s (Eck and Wells 1987). With the shift to predominantly offshore stocking in 1986, predation on slimy sculpins in areas of the lake trawled by USGS-GLSC likely declined, and this decline in predation allowed the increase in slimy sculpin abundance observed during the 1990s. Slimy sculpins in Lake Michigan have fed predominantly on Diporeia since the 1960s (Davis et al. 1997).

\section{Dynamics of the salmonine community}

\section{Background}

Stocking of salmonine fishes into Lake Michigan has had a profound effect on the lake's food web. Large-scale stocking of salmonines began in 1965, and has continued to the present. The rationale for stocking salmonines was (i) to control abundance of alewives, which had become a nuisance, (ii) to initiate a valuable sport fishery, (iii) to possibly initiate naturalized populations of introduced salmonines, and (iv) to rehabilitate the lake trout population (Holey et al. 1995; Rutherford 1997). The five species of salmonines currently stocked in Lake Michigan are lake trout, chinook salmon (Oncorhynchus tshawytscha), coho salmon
(Oncorhynchus kisutch), rainbow trout (Oncorhynchus mykiss), and brown trout (Salmo trutta).

\section{Long-term trends in biomass, production, and consumption}

Lake-wide biomass and production of the five salmonine species was estimated using age-specific population models to track abundance at age over time. For all species except chinook salmon, our modeling approach was similar to the one used by Jones et al. (1993) for Lake Ontario salmonines. Using estimates of gross conversion efficiency (GCE) from bioenergetics modeling (Stewart and Ibarra 1991), lake-wide consumption of prey by salmonine populations was calculated using the production-conversion efficiency method of Ney (1990) where gross production is divided by GCE to estimate consumption. For chinook salmon, population modeling techniques outlined in Benjamin and Bence (2002) were used to estimate biomass, production, and consumption. Recruitment was quantified as the number of individuals entering the lake population, and equaled the sum of hatchery and naturally reproduced production. Salmonine stocking records have been summarized by the U.S. Fish and Wildlife Service (C. Bronte, Green Bay Fishery Resources Office, Green Bay, WI 54311, U.S.A., salmonine stocking database) and Benjamin (1998). Natural reproduction by chinook and coho salmon, as well as rainbow trout, was quantified using previously developed methods (Rutherford 1997). We assumed that natural recruitment to lake trout and brown trout populations has been negligible since 1965 (Holey et al. 1995; Rutherford 1997).

Salmonine biomass in Lake Michigan increased from $0.039 \mathrm{kt}$ in 1965 to nearly $27 \mathrm{kt}$ in 1986, then declined during the late 1980 s, driven by a decline in abundance of chinook salmon, which has accounted for over $40 \%$ of the total salmonine biomass since 1980 (Fig. 4b). This decrease in chinook salmon biomass has been attributed to an outbreak of bacterial kidney disease (BKD) within the chinook salmon population (Kabre 1993). Presumably due to a decrease in BKD-induced mortality, chinook salmon biomass increased during 1994-1998, and salmonine biomass was estimated at nearly $30 \mathrm{kt}$ in 1998 (Fig. 4b). For the most part, temporal trends in gross production mimicked trends in salmonine biomass. Annual gross production of salmonine biomass increased from $0.235 \mathrm{kt}$ in 1965 to nearly $23 \mathrm{kt}$ in 1998. Ratio of annual gross production to biomass (P/B) generally varied from 0.8 to 1.0 .

Consumption of prey by Lake Michigan salmonines increased from only $1 \mathrm{kt}$ in 1965 to $130.5 \mathrm{kt}$ in 1998 (Fig. 8). Since 1977, the chinook salmon population has been responsible for approximately $50 \%$ of the consumption by salmonines (Fig. 8a). Most predation by salmonines in Lake Michigan has been directed at alewives (Fig. 8b). Alewives (both small and large sizes combined) represented, on average, $69.2 \%$ of total annual consumption from 1985 to 1998 , with a maximum of $79.7 \%$ in 1998 . Annual consumption of alewives by salmonines exceeded $90 \mathrm{kt}$ in 1996 and 1998. Chinook salmon have been responsible for $62 \%$ of the predation on alewives by salmonines since 1980 .

An important factor driving salmonine biomass and production, as well as consumption of prey by salmonines, was trends in the recruitment of young fish to the salmonine 
Fig. 8. (a) Estimated consumption of prey by lake trout (light shading), brown trout (dark shading), rainbow trout (open), coho salmon (vertical bars), and chinook salmon (solid) in Lake Michigan, 1965-1998. (b) Estimated consumption of large alewives (solid), small alewives (open), and other fish (shading) by salmonines in Lake Michigan, 1965-1998. Consumption was estimated using age-specific population models coupled with bioenergetics models. See text for more details on modeling.

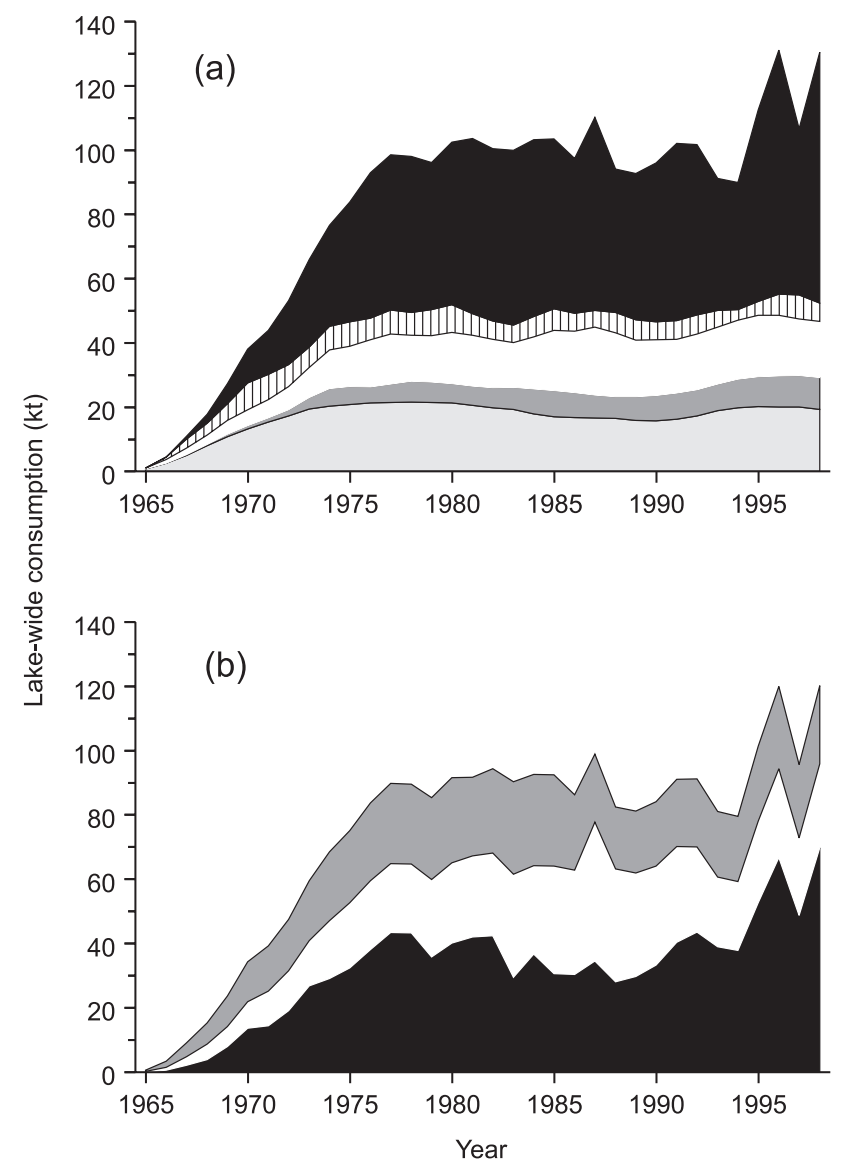

stocks. Natural recruitment of chinook salmon has increased from 1970 to the present. We estimated that annual natural recruitment of chinook salmon approached 2 million smolts during the 1990s. In some years, natural recruitment represented nearly $40 \%$ of the total annual recruitment of chinook salmon (Rutherford 1997).

\section{Long-term trends in diet and growth}

Growth rate of chinook salmon in Lake Michigan declined during the early 1980s (Stewart and Ibarra 1991), but then increased during the late 1980s and early 1990s (Wesley 1996). The increase could have been a compensatory response to the decline in chinook salmon abundance following the BKD outbreak (Wesley 1996). Growth rate again declined during the late 1990s. Alewife has always been the most prominent component of chinook salmon diet. However, alewife was of greater importance in chinook salmon diet during the 1970s than during 1983-1987, when rainbow smelt was an important diet constituent and when alewives in the diet tended to be smaller than in the 1970s or 1994-1995 (Stewart and Ibarra 1991; R. Elliott, U.S. Fish and Wildlife Service, Green Bay, WI 54311, U.S.A., personal communication).

Growth rate of lake trout remained relatively constant between the 1970s and 2000 (Madenjian et al. 1998a; J. Jonas, Michigan Department of Natural Resources, Charlevoix, MI 49720, U.S.A., unpublished data). Overall, alewife has remained the most important component in adult lake trout diet. Nevertheless, bloater was a noteworthy constituent, contributing up to $35 \%$ of the diet of adult lake trout in nearshore waters of southeastern Lake Michigan between 1985 and 1995. In contrast, adult lake trout diet in nearshore Wisconsin waters did not appear to change appreciably since the 1970s (Madenjian et al. 1998a). Lipid content of lake trout in Lake Michigan did not substantially change between 1970 and 1995 (Madenjian et al. 2000).

\section{Changing fisheries}

Sport fisheries for Lake Michigan salmonines greatly expanded from the mid-1960s to 1985 , in response to increased salmonine abundance (Bence and Smith 1999). With decline of chinook salmon abundance in the late 1980s, angling effort declined. Harvest of rainbow trout increased during the late 1980s and has remained relatively high during the 1990s (Bence and Smith 1999). Chinook salmon harvest nearly doubled between 1994 and 1998, but the 1998 harvest was still less than $30 \%$ of the 1986 harvest. Lake trout have been harvested continually both recreationally and commercially since 1970 (Bence and Smith 1999).

\section{Lake trout rehabilitation}

Lake trout were extirpated from Lake Michigan during the 1950s, presumably because of overfishing and sea lamprey predation (Wells and McLain 1973). Since 1965, an average of about 2.4 million lake trout yearlings have been stocked into Lake Michigan each year. As part of the lake trout rehabilitation effort, two offshore refuges were established during 1984-1985 (Holey et al. 1995). The Northern Refuge encompassed a complex of shallow-water (0- to 20-m) spawning reefs, whereas the Southern or Midlake Refuge included four large deep-water (45- to 80-m) spawning reefs. Fishing for lake trout continues to be prohibited in both refuges. Emphasis on stocking the two refuges began in 1986 , when stocking rates in nearshore zones sharply declined.

Although the stocking program has yielded a substantial number of spawners, documentation of natural reproduction by lake trout in Lake Michigan since 1965 has been extremely sparse (Holey et al. 1995). This negligible amount of successful natural reproduction appeared to be due to several factors. Contaminants, once thought to strongly interfere with lake trout reproduction in Lake Michigan, have recently been shown not to be a significant hindrance, while thiamine deficiency is now seen as a likely factor (Fitzsimons et al. 1999). By previously established criteria, density of spawning lake trout in the Northern Refuge was sufficiently high to allow for successful natural reproduction (Madenjian and DeSorcie 1999). Perhaps hatchery reared lake trout are so inefficient at reproducing that considerably higher densities of spawners or a higher density of older (age $>10$ years) spawners are required for successful natural reproduction. Density of lake trout spawners on Sheboygan Reef in the Midlake Refuge exceeded the relatively high density of 175 
Fig. 9. Annual commercial harvest of lake whitefish from Lake Michigan, 1970-1998.

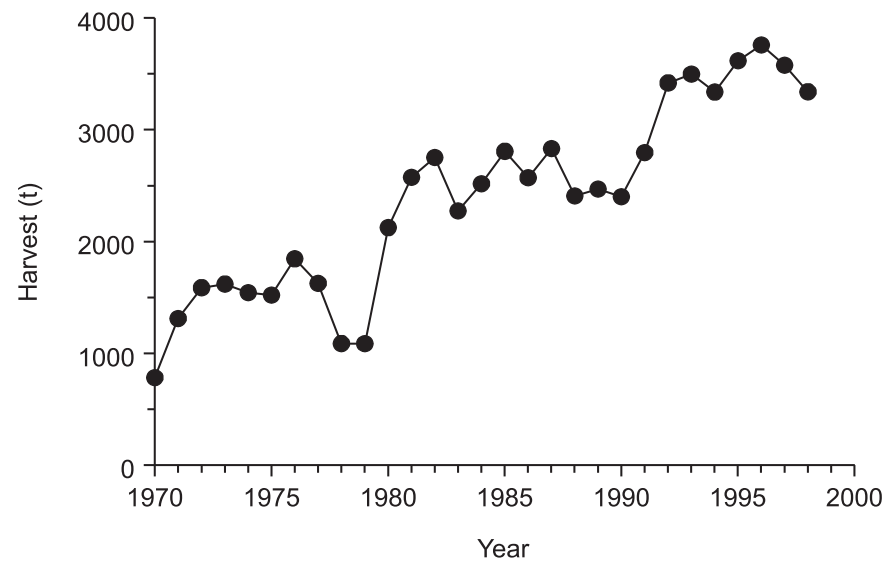

fish per $305 \mathrm{~m}$ of gill net during the late 1990s and a substantial proportion of these spawners was composed of fish $>10$ years old, yet no signs of natural recruitment have been observed (M. Toneys and P. McKee, Wisconsin Department of Natural Resources, Sturgeon Bay, WI 54235, U.S.A., unpublished data). Perhaps alewife predation on lake trout fry has also been playing an important role in suppressing natural reproduction by lake trout (Krueger et al. 1995).

\section{Dynamics of other fish populations}

\section{Sea lamprey}

Treatment of Lake Michigan tributaries, beginning in the late 1950s, with the lampricide 3-trifluoromethyl-4nitrophenol (TFM) led to an estimated 80-90\% decline in the abundance of adult sea lamprey in Lake Michigan by 1966 (Lavis et al. 2002). Lampricide treatment in streams continues to be the primary strategy for controlling the sea lamprey population in Lake Michigan.

Population sizes of spawning-phase sea lamprey in all Lake Michigan tributaries each year since 1977 have been estimated using a regression model, which incorporated relative abundance data from assessment traps in tributaries and estimates of stream discharge rates (Lavis et al. 2002). This long-term series indicates that numbers of spawning sea lampreys in Lake Michigan tributaries increased during 1977-1984, showed no trend between 1984 and 1995, and then increased again during 1995-1999. The two increases occurred primarily in northern tributaries to the lake. The first increase was attributed to an immigration of adult sea lampreys from northern Lake Huron, whereas the second increase was probably due to a decrease in sea lamprey control measures for Lake Michigan (G. Christie, Great Lakes Fishery Commission, Ann Arbor, MI 48105, U.S.A., personal communication). Lake-wide estimates of spawning sea lamprey population size ranged between 32000 and 117000 sea lampreys (Lavis et al. 2002).

Long-term trends for incidence of fresh sea lamprey wounds on lake trout in Lake Michigan mimicked long-term trends for sea lamprey abundance. Wounding rates in southern waters of the lake have remained nearly unchanged for the last 25 years, whereas an increase in wounding rates has been observed in northeastern waters since 1978 (Lavis et al. 2002). Overall, lamprey-induced annual mortality, estimated

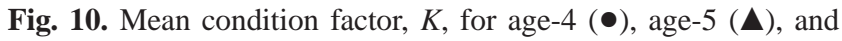
age-6 (-) lake whitefish in northern Lake Michigan, 1985-1998. $K=10^{5} \cdot W \cdot L^{-3}$, where $W$ is weight $(\mathrm{g})$ and $L$ is total length $(\mathrm{mm})$.

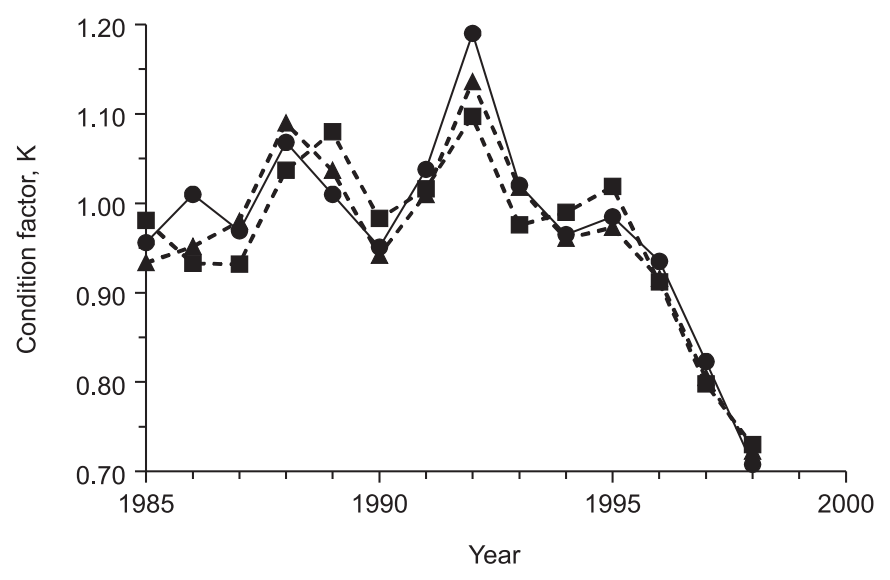

from wounding rate, for Lake Michigan lake trout was relatively low, averaging less than $7 \%$ for most years during 1984-1998.

\section{Lake whitefish}

Lake whitefish is the most important commercial fish in Lake Michigan. Tribal and state-licensed commercial fishers from Michigan and Wisconsin continue to exploit lake whitefish. Lake whitefish are taken in trap nets, gill nets, trawls, and pound nets.

Since 1970, annual commercial harvest of lake whitefish has more than tripled (Fig. 9), reflecting a lake-wide increase in abundance. A dramatic decline in lake whitefish abundance during the late 1950s was linked primarily with sea lamprey predation (Wells and McLain 1972). Thus, there can be little doubt that the impressive recovery of the lake whitefish population in Lake Michigan since 1970 was partially driven by sea lamprey control (Eck and Wells 1987). Stocking of lake trout also afforded extra protection from sea lamprey predation because lake trout are favored prey for sea lampreys (Wells and McLain 1972). The decrease in mean size of adult rainbow smelt during the 1970s and 1980s and decreased rainbow smelt abundance during the 1990s may have also contributed to the lake whitefish recovery because large rainbow smelt may prey upon lake whitefish fry (Wells and McLain 1973). During the last 30 years, exploitation has not impaired the ability of the adult lake whitefish population to produce large year-classes. This is true even though contemporary stocks of lake whitefish have been subjected to high exploitation rates, leading to total annual mortality that sometimes exceeded 80\% (M. Ebener and J. Bence, unpublished data).

Lake whitefish size-at-age declined in Lake Michigan during the 1990s. Moreover, condition factor dropped rapidly between 1995 and 1998 (Fig. 10). Reduced growth rate during the 1990s may have resulted from density-dependent factors, as sustained high levels of lake whitefish abundance resulted in increased intraspecific competition for food resources. Other factors may also have been involved. For example, zebra mussel density increased substantially in northern Lake Michigan during the same time that lake whitefish condition declined precipitously (T. Nalepa, un- 
published data). Hoyle et al. (1999) linked poor body condition of lake whitefish in Lake Ontario with zebra mussel invasion of the lake; perhaps expansion of the zebra mussel population also had a negative effect on lake whitefish condition in Lake Michigan.

\section{Burbot}

Diet of adult burbot (Lota lota) in Lake Michigan has been diverse and has included both fish and benthic invertebrates, especially crayfish (Fratt et al. 1997; S. Hart and J. Jonas, Michigan Department of Natural Resources, Charlevoix, MI 49720, U.S.A., unpublished data). In deeper waters (>39 m), deepwater sculpin has been an important component of burbot diet since the 1930s.

The burbot population in Lake Michigan was greatly reduced in size because of sea lamprey predation during the 1950s (Wells and McLain 1973). Recovery of the population began, albeit very slowly, during the late 1960s and 1970s (Eck and Wells 1987). However, rapid increase in abundance occurred in the 1980s (Fig. 7). Thus, burbot recovery was delayed for more than 10 years compared with lake whitefish recovery, even though both recoveries are attributed to sea lamprey control. Eshenroder and Burnham-Curtis (1999) contended that this delay was due to alewife interference with burbot reproduction. Burbot larvae are pelagic; therefore, they are susceptible to predation by alewives. Alewife density may have decreased sufficiently during the 1970 s to allow for a strong recovery by the burbot population during the 1980s. According to bottom trawl surveys conducted by the USGS-GLSC, lake-wide abundance of burbot increased exponentially during the 1980s and then leveled off during the 1990s (Fig. 7). As mentioned above, patterns in the long-term series for abundances, coupled with diet data for burbot, suggested that predation by burbot has maintained the deepwater sculpin population at a level lower than that observed during the early 1980s (Figs. 6 and 7). Based on GLSC bottom trawl surveys, lake-wide biomass of burbot in Lake Michigan proper averaged about 9.7 kt during 1990-1999.

\section{Yellow perch}

The yellow perch population in Lake Michigan has yielded valuable sport and commercial fisheries (Wells and McLain 1973). During the 1980s and 1990s, yellow perch was the most popular sport-caught fish (Bence and Smith 1999).

Decline in yellow perch abundance in Lake Michigan during the 1960s has been attributed to the alewife invasion (Wells 1977), indicating that the levels of alewives characteristic of the 1960s and early 1970s were sufficiently high to interfere with yellow perch reproduction.

With strong year-classes produced in 1980 and 19831988, yellow perch abundance in Lake Michigan increased during the 1980s (Jude and Tesar 1985; Eck and Wells 1987; Makauskas and Clapp 2000). This recovery in the yellow perch population has been attributed to the decline in alewife abundance during the 1970s (Jude and Tesar 1985; Eck and Wells 1987). Lake-wide abundance of yellow perch remained relatively high during 1985-1990, but then decreased during 1990-1995 because year-class strength was weak during 1989-1993 (Makauskas and Clapp 2000). Year- class strength remained weak during 1995-1997 and in 1999, but was moderate in 1998. No single factor could explain poor recruitment of yellow perch in Lake Michigan proper between 1989 and 1997. Lake-wide abundance of alewife was as low during 1989-1997 as it was during 1983-1988 (Fig. 4), and therefore it seems unlikely that interference by alewives was primarily responsible for poor recruitment during 1989-1997 throughout the lake. Nonetheless, Shroyer and McComish (2000) reported a negative relationship between yellow perch year-class strength and alewife abundance in Indiana waters of Lake Michigan during 1984-1996. Skewing of the sex ratio (more males than females) during 1992-1996 may have partially contributed to poor recruitment (Makauskas and Clapp 2000). Skewed sex ratio in the yellow perch population may have been due to commercial harvest operations, because females grow faster than males and the commercial fishery targets larger individuals. Perhaps the number of female spawners was so diminished that the probability of producing a moderate or large size year-class was low. During some years, slow rate of warming of nearshore waters in the spring may have partially contributed to production of weak year-classes (Makauskas and Clapp 2000). Finally, data from Illinois waters suggested that bottom-up effects, namely low zooplankton abundance during June and July, may also have been partly responsible for poor recruitment, presumably because survival of yellow perch fry was reduced due to low food availability (Makauskas and Clapp 2000).

\section{Walleye}

Walleye (Stizostedion vitreum) has been one of the most ecologically and economically important fishes in Michigan waters of Green Bay (Schneeberger 2000). Other centers of relatively high walleye density in Lake Michigan included southern Green Bay and the Muskegon vicinity of eastern Lake Michigan. Walleye abundance in Lake Michigan fluctuated greatly during the 1900 s and these fluctuations have been attributed to overexploitation, deterioration of water quality (in southern Green Bay), loss of habitat (in southern Green Bay), and interference by alewives with walleye reproduction.

Walleye abundance in Green Bay declined precipitously during the 1960s, but rebounded during the 1970s because of management actions that included stocking and imposition of restrictions on commercial and recreational fishing (Schneeberger 2000). Today, the walleye population in Little Bay de Noc (northern Green Bay) supports a world-class recreational fishery, and reduction in stocking rates is now being considered by managers because the fishery is nearly self-sustaining. Walleye diet in northern Green Bay has remained consistent between the 1960s and 1990s, with rainbow smelt and alewives representing the bulk of the diet (Schneeberger 2000).

\section{Lake sturgeon}

Population size of lake sturgeon (Acipenser fulvescens) (for individuals $\geq 22.7 \mathrm{~kg}$ in weight) in Lake Michigan during 1825-1890 has been estimated to have been between 145000 and 2406000 individuals (Hay-Chmielewski and Whelan 1997). The lake sturgeon population in Lake Michigan collapsed during the early 1900s owing to over- 
exploitation and habitat degradation (Wells and McLain 1973). During the 1990s, small populations of lake sturgeon have been associated with at least 13 tributaries (HayChmielewski and Whelan 1997). With continued removal of dams on tributaries anticipated in the near future, the size of lake sturgeon population in Lake Michigan should increase as more suitable spawning habitat becomes available.

\section{Emerald shiner}

The emerald shiner (Notropis atherinoides) population in Lake Michigan crashed during the early 1960s, coincident with buildup of the alewife population (Wells and McLain 1973). Apparently, alewives fed on the pelagic eggs and larvae of the emerald shiner. Emerald shiner abundance has remained at very low levels during 1970-2000 (D. Jude, unpublished data; J. Dettmers, Illinois Natural History Survey, Zion, IL 60099, U.S.A., unpublished data; R. Rost, Wisconsin Department of Natural Resources, Peshtigo, WI 54157, U.S.A., unpublished data), suggesting that the relatively low alewife abundance during 1984-2000 was still sufficiently high to interfere with emerald shiner reproduction.

\section{Round goby}

The round goby, an invader from the Ponto-Caspian region, established populations in Calumet Harbor (southern Lake Michigan) and in several harbors on both the east and west sides of Lake Michigan including Milwaukee, Sturgeon Bay, Escanaba, Grand Haven, Muskegon, and Charlevoix during the 1990s (Clapp et al. 2001). Zebra mussels form a substantial portion of the diet of round gobies in the Great Lakes (C. Knight, Ohio Department of Natural Resources, Fairport, $\mathrm{OH}$ 44077, U.S.A., personal communication; M. Thomas, Michigan Department of Natural Resources, Mt. Clemens, MI 48045, U.S.A., personal communication). In turn, round gobies are preyed upon by several species of fish. The precipitous decline of mottled sculpin (Cottus bairdi) abundance in Calumet Harbor, as well as decreases in abundances of johnny darter (Etheostoma nigrum) and logperch (Percina caprodes) in Lake St. Clair, has been linked to the round goby invasion (Janssen and Jude 2001; M. Thomas, Michigan Department of Natural Resources, Mt. Clemens, MI 48045, U.S.A., personal communication). It remains to be seen whether these seemingly negative effects of round gobies on sculpins and darters will be confined to shallow and protected waters of Lake Michigan.

\section{Lake herring}

Lake herring (Coregonus artedi) was once a prominent member of the fish community in Lake Michigan, and the lake herring population once supported a valuable commercial fishery (Wells and McLain 1973). The crash in the lake herring population during the 1950 s has been attributed to overexploitation and interference by rainbow smelt with lake herring reproduction (Wells and McLain 1973). Although there have been no signs of a lake-wide recovery, a recent increase in lake herring abundance in Grand Traverse Bay of northern Lake Michigan has been observed. Sport harvest of lake herring in Grand Traverse Bay indicated the presence of lake herring at very low levels in 1985 and 1993, but sport harvest increased three- to seven-fold during 1995-1998 compared with the 1993 harvest (G. Rakoczy, Michigan De- partment of Natural Resources, Charlevoix, MI 49720, U.S.A., personal communication).

\section{Contaminants and global climate change stressors}

\section{Contaminants}

The issue of contaminants acting as stressors to Great Lakes biota emerged in the 1970s (Evans 1988). Consequently, the governments of the United States and Canada negotiated the Great Lakes Water Quality Agreement in 1972, and revised this agreement in 1978. This agreement led to many remedial actions to improve the quality of Great Lakes waters. Additionally, production of polychlorinated biphenyls (PCBs) was banned, use of the pesticide DDT (1,1,1-trichloro-2,2-bis[ $p$-chlorophenyl]ethane) was discontinued, and uses of the organochlorine pesticides chlordane and dieldrin were restricted in both the United States and Canada during the 1970s.

As a consequence of the abovementioned measures, concentrations of most contaminants in Lake Michigan biota decreased substantially between 1970 and 2000. For example, total PCB concentration in Lake Michigan zooplankton decreased between 1982 and 1995 (A. Trowbridge and D. Swackhamer, University of Minnesota, Minneapolis, MN 55455, U.S.A., personal communication). Total PCB concentration in Mysis, Diporeia, prey fishes, and salmonines of Lake Michigan decreased by roughly an order of magnitude between 1975 and 1995 (DeVault et al. 1996; Madenjian et al. $1998 b, 1998 c$ ). During the 1970s and early 1980s, decreases were observed in total DDT, dieldrin, and oxychlordane concentrations in lake trout (DeVault et al. 1996), and in PCB, oxychlordane, DDT, and dieldrin concentrations in herring gull (Larus argentatus) eggs (Pekarik and Weseloh 1998). In contrast, toxaphene concentrations in lake trout did not decrease between 1986 and 1992 (DeVault et al. 1996).

Very few lake-wide temporal changes in Lake Michigan biota between 1970 and 2000 have been shown to be directly linked to stressor effects exerted by contaminants. The dramatic increase in double-crested cormorant (Phalacrocorax auritus) population size during the late 1980s and 1990s was due, at least in part, to the substantial reduction of contaminant levels within the lake ecosystem during the 1970s (Weseloh et al. 1995). Number of double-crested cormorant nests on islands within Lake Michigan (including Green Bay) increased exponentially from 75 nests in 1977 to 4743 nests during 1989-1990, and then to 28158 nests in 1997 (F.J. Cuthbert, University of Minnesota, St. Paul, MN 55108, U.S.A., personal communication). Weseloh et al. (1983) documented shell thinning with high egg breakage and high egg loss (95\%) with concomitant reproductive failure in Great Lakes cormorants during the early 1970s, and also reported high DDE (a metabolite of DDT) concentrations in cormorant eggs. Apparently, high concentration of DDE in the cormorants was causing eggshell thinning and reproductive failure. Increased predation by the exploding population of double-crested cormorants in Lake Michigan may have caused a reduction in abundance of smallmouth bass (Micropterus dolomieui) in the vicinity of Beaver Island in northern Lake Michigan; however, research results to date 
are not conclusive (D. Peterson, Central Michigan University, Mt. Pleasant, MI 48859, U.S.A., personal communication). To the best of our knowledge, no lake-wide temporal changes in phytoplankton communities, benthic invertebrate communities, zooplankton communities, or fish communities in Lake Michigan have been shown to be directly attributable to contaminant effects (Evans 1988). Nevertheless, contaminants may have influenced health of brown bullhead (Ameiurus nebulosus) populations in certain tributaries (Baumann et al. 1996).

\section{Global climate change}

An increase in atmospheric carbon dioxide enhances heat retention (Regier et al. 1990). Burning fossil fuels and changes in land use are correlated with an increase in carbon dioxide concentration in the earth's atmosphere, and therefore global climate change likely represents an anthropogenic stressor to the global environment. Although not all climatologists agree as to the nature, extent, intensity, and timing of the effects of increased carbon dioxide content in the earth's atmosphere, there is general consensus that climate warming will occur (Regier et al. 1990; Doak and Morris 1999).

Magnuson et al. (1997) predicted the effects of changes in thermal regimes associated with global climate change on primary production, zooplankton biomass, maximum sustainable fishery yield, growth and consumption by fish, fish reproduction and overwinter survival, success of invasions by exotic fish species, and dissolved oxygen concentration in the Great Lakes. For Lake Michigan, McCormick (1990) used computer simulation modeling to explore potential changes in thermal structure and cycle of Lake Michigan under three different scenarios for global climate change. Using predictions from McCormick (1990), Magnuson et al. (1990) forecasted that thermal habitat within Lake Michigan will increase under global warming scenarios for fish species from all thermal guilds. Additionally, Magnuson et al. (1997) reported that global warming has been predicted to eventually cause a 0.99 - to 2.48 -m decrease in Lake Michigan's water level; however, these researchers did not specifically address effects of this lowering of lake level on Lake Michigan biota.

Based on available data, we are unable to ascribe any of the lake-wide changes in the Lake Michigan food web during 1970-2000 to global climate change, mainly because insufficient data are available to establish long-term, lake-wide trends in water temperature characteristics in Lake Michigan or to clearly show that a long-term trend in water temperature characteristics is linked to global climate change. Longterm trends in water temperatures were not consistent between two sites in Lake Michigan, including one site at St. Joseph, along the southeastern shore of Lake Michigan, and another at the southern end of Green Bay (McCormick and Fahnenstiel 1999). Moreover, even though the duration of summer thermal stratification increased significantly at St. Joseph during 1960-1992, McCormick and Fahnenstiel (1999) cautioned that the series did not extend far enough back in time to resolve whether the trend was part of a natural cycle or was caused by anthropogenic activity. Finally, recent low water levels in Lake Michigan can be explained by quasi-periodicity in water level fluctuations (periods of roughly 30 and 150 years) and by unusually low rainfall during 1998 and 1999, without evoking a global climate change effect (T. Thompson, Indiana Geological Survey, Bloomington, IN 47405, U.S.A., personal communication).

\section{Discussion}

\section{Sea lamprey control and top-down effects}

Whereas Wells and McLain (1973) concluded that sea lamprey and alewife invasions had a greater effect on the Lake Michigan fish community than any of the other anthropogenic stressors during 1940-1970, control of sea lamprey and alewife populations was paramount in effecting changes within the Lake Michigan ecosystem during 19702000. Spectacular recovery of the lake whitefish population in Lake Michigan between 1965 and 2000 was partially attributable to sea lamprey control. Further, control of sea lamprey, beginning in the 1950 s, enabled the successful stocking effort launched during the 1960s to increase salmonine biomass. In turn, salmonine populations, especially the chinook salmon population, were primarily responsible for the decline in alewife abundance during the 1970s and early 1980s. Strong recovery of burbot during the 1980s was probably fueled by control of both sea lamprey and alewife. Moreover, recovery of deepwater sculpin during the 1970s was most likely facilitated by reduction in alewife density. Also, relaxation of the interference effect by alewives on yellow perch reproduction is the most plausible explanation for the rapid increase in yellow perch abundance during the 1980s. Finally, the sudden increase in abundance of the very large-bodied cladoceran D. pulicaria during the 1980 s was probably also due to reduction in alewife abundance.

Evidence that predation by salmonines drove the reduction in alewife abundance is strong. Decline in alewife abundance during the 1970s and early 1980s was well synchronized with buildup of salmonine populations. Moreover, the period of relatively low alewife abundance between 1984 and 2000 coincided with high predation by salmonines on alewives, as estimated by our modeling. Alewives have dominated salmonine diets in Lake Michigan from the 1960s through the 1990s. Additionally, annual alewife abundance since the early 1970 s was much better correlated with estimates of annual consumption of alewives by salmonines than with cold temperatures. Based on our estimates of alewife consumption by salmonines, the commercial fishery for alewives was a relatively minor contributor to the observed decrease in alewife abundance. Annual commercial harvest of alewives from Lake Michigan averaged about $15 \mathrm{kt}$ during 1973-1984 (S. Nelson, USGS-GLSC COMCAT database, Ann Arbor, MI 48105, U.S.A.), whereas annual consumption of alewives by salmonines averaged about 60 kt over the same time period. The Lake Michigan commercial fishery for alewives was closed in 1991 and has not been reopened.

Intensive stocking of salmon and trout into Lake Michigan can be viewed as a manipulation of the ecosystem. Lakewide monitoring of prey fish populations has provided considerable insight into predator-prey dynamics within the Lake Michigan ecosystem. Predator-prey interaction between chinook salmon and alewife has been one of the strongest trophic links within the ecosystem since the 1970s. 
Continued monitoring of prey fish populations, as well as surveillance of other components of the ecosystem, should provide further understanding of the Lake Michigan food web. Such long-term studies are especially appropriate for ecosystem manipulations (Pace and Cole 1989).

\section{Bottom-up effects}

Several changes within the Lake Michigan ecosystem during 1970-2000 may be attributable to bottom-up effects. Decline in abundance of all three dominant benthic macroinvertebrate groups, including Diporeia, oligochaetes, and sphaeriids, between 1980 and 1993 in nearshore $(\leq 50 \mathrm{~m}$ deep) waters of Lake Michigan was believed to be chiefly due to a decrease in primary production in nearshore waters. Although long-term data for spring total phosphorus, an indicator of primary production, in nearshore waters of Lake Michigan were not available, comparison of measurements during 1998-2000 with measurements from the early 1970s suggested a decrease in primary production over this time period. In contrast, long-term data were readily available for offshore waters, and these data showed no long-term trend in primary production during 1973-1998. Similarly, abundances of the three major groups of benthic macroinvertebrates in offshore waters did not trend upward or downward during this time period. The apparent decline in primary production in nearshore waters of Lake Michigan between the 1970s and 1998-2000 was likely due to the decrease in phosphorus loadings between 1980 and 1987. The continued decrease in Diporeia abundance during the 1990s in nearshore waters of southern and southeastern Lake Michigan coincided with the zebra mussel invasion, although a specific mechanism whereby zebra mussels may have reduced Diporeia abundance remains unidentified.

Have bottom-up effects, including the apparent reduction in nearshore primary production and the continued decline of Diporeia, already precipitated a decrease in abundances of important fish populations in Lake Michigan? No clear effects are evident yet. The decrease in bloater abundance during the 1990s was attributed to an extended period of very low recruitment, which may be related to intraspecific mechanisms rather than bottom-up effects. Lake-wide abundances of alewife, salmonines, burbot, lake whitefish, and sculpins have not decreased during the 1990s. Even though data from Illinois waters suggested that bottom-up effects may have partly contributed to a prolonged period of low yellow perch recruitment, available data were insufficient to support the contention that a long-term decrease in zooplankton abundance was primarily responsible for the extended period of low recruitment. Rainbow smelt abundance decreased during 1992-1999; however, explanations for trends in rainbow smelt abundance, as determined by GLSC bottom trawl surveys over the past 30 years, are not obvious. Eck and Wells (1987) also experienced difficulty in interpreting long-term trends in rainbow smelt abundance.

Have these bottom-up effects already influenced growth rates or condition of Lake Michigan fishes? The decrease in lake whitefish condition between 1995 and 1998 may have been partially due to some bottom-up effects. An increase in proportion of zebra mussels or a decrease in proportion of Diporeia in lake whitefish diet could have led to reduced lake whitefish condition. The recent decline in alewife con- dition may be due to bottom-up effects. Bloater growth rate declined between 1973 and 1994, during which time the population increased tremendously in size. However, bloater growth rate has actually increased during 1994-1999, as the population has undergone a drastic decrease in size. To detect future impacts of bottom-up effects on fish populations, surveillance of fish abundance, growth rates, lipid content, and condition should be continued. Zebra mussel abundance in Lake Michigan has not yet peaked, and the quagga mussel (Dreissena bugensis) invasion of Lake Michigan has just begun (Nalepa et al. 2001).

\section{Overexploitation of fish stocks}

Overall, overexploitation of fish populations appeared to play a relatively minor role in shaping the Lake Michigan food web during 1970-2000. Commercial harvest of yellow perch during the 1990s may have contributed to a skewing of the sex ratio (relatively low number of female spawners), which may have contributed to prolonging the period of low recruitment to the yellow perch population. Yellow perch recruitment remained low during 1989-1997. Consequently, the yellow perch commercial fishery in Lake Michigan was closed by 1998 .

\section{Bythotrephes and round goby invasions}

Although invasions by Bythotrephes and round goby have caused some changes to the Lake Michigan food web during the late 1980s and 1990s, the earlier invasions by sea lamprey and alewife had more serious consequences for the Lake Michigan fish community. Through predation, Bythotrephes may have reduced the abundance of certain smaller cladocerans. However, the impact of this reduction on the rest of the Lake Michigan ecosystem remains undefined. Total phytoplankton biomass in offshore waters has exhibited no long-term trends since the early 1970s. Although species composition of the zooplankton community has undergone substantial changes, total zooplankton biomass in offshore waters of Lake Michigan has shown no long-term trends since the 1970s. Abundance of Mysis in offshore waters has not changed appreciably since the 1970s. Alewife abundance has neither increased nor decreased since the time of the Bythotrephes invasion, and salmonine biomass has remained relatively high throughout the occupation of the lake by Bythotrephes. Moreover, Bythotrephes has been a relatively minor component of the diets of the prey fish and salmonine communities in Lake Michigan since the late 1980s (Davis et al. 1997; R. Elliott, U.S. Fish and Wildlife Service, Green Bay, WI 54311, U.S.A., personal communication). The round goby invasion was linked to the decline of mottled sculpin in Calumet Harbor. To date, however, no lake-wide changes in abundance of any Lake Michigan biota have been ascribed to the round goby invasion.

\section{Contaminants and global climate change stressors}

Although bans on use of pesticides and PCBs have led to dramatic declines in contaminant concentrations of Lake Michigan biota between 1970 and 2000, very few lake-wide changes in abundances of Lake Michigan biota have been shown to be directly attributable to stressor effects from contaminants. Rapid increase in the double-crested cormorant 
population associated with Lake Michigan during the late 1980s and 1990s was partially due to substantial reduction of contaminant levels within the lake ecosystem during the 1970s (Weseloh et al. 1995). To date, lake-wide consequences of this increase in cormorant abundance on the rest of the lake ecosystem remain unclear.

We were unable to attribute any of the lake-wide changes in the Lake Michigan food web between 1970 and 2000 to global climate change effects. That is not to say that global climate change has not already had some effect on the Lake Michigan ecosystem. Rather, time series for water temperature characteristics are not sufficiently long to resolve whether recent trends were part of a natural cycle or were forced by anthropogenic activity. Furthermore, insufficient data were available to identify a common long-term trend in water temperature characteristics across several locations in the lake. We would expect that ecological changes associated with global climate change would occur much more slowly than changes induced by invasions of exotic species.

\section{Other effects}

Finally, we would like to point out that one of the major changes occurring in the Lake Michigan food web between 1970 and 2000 may not have been driven by any of the anthropogenic stressors mentioned above. Rise in bloater abundance during the 1980s and fall in bloater abundance during the 1990s may simply have represented natural oscillations in bloater population size. In other words, bloater abundance may exhibit quasi-regular natural cycles, with a period of approximately 30 years. Through densitydependent mechanisms, bloaters may be regulating their own abundance, largely independent of human interventions or interactions with other fishes. Given that bloater longevity in Lake Michigan is at least 12 years (G. Fleischer, unpublished data), a 30-year cycle in their abundance would be in accord with theory developed by Nisbet (1997) for delayedfeeback population cycles.

\section{Acknowledgments}

This paper would not have been possible without the efforts of the Lake Michigan Technical Committee, including chairperson M. Holey, as well as D. Clapp, B. Eggold, R. Hess, J. Kubisiak, S. Marcquenski, E. Olson, M. Toneys, and G. Wright. We thank L. Wells, senior author of the SCOL-1 paper for Lake Michigan, for providing helpful comments. M. Hansen and S. Kerr also reviewed the manuscript. With this paper, we pay tribute to the memory of Heang T. Tin, a pioneer of larval fish ecology in Lake Michigan. This work was supported in part by Michigan Sea Grant College Program grants R/FM-1 and R/GL-46 to J.R.B. This article is Contribution 1172 of the USGS-GLSC, GLERL contribution No. 1224, and CGLAS contribution No. 622. This publication is a result of work sponsored by the Cooperative Institute for Limnology and Ecosystems Research under cooperative agreement NA67RJ0148 from the Office of Oceanic and Atmospheric Research, National Oceanic and Atmospheric Administration, U.S. Department of Commerce.

\section{References}

Baumann, P.C., Smith, I.R., and Metcalfe, C.D. 1996. Linkages be- tween chemical contaminants and tumors in benthic Great Lakes fish. J. Gt. Lakes Res. 22: 131-152.

Bence, J.R., and Smith, K.D. 1999. An overview of recreational fisheries of the Great Lakes. In Great Lakes fisheries and policy management: a binational perspective. Edited by W.W. Taylor and C.P. Ferreri. Michigan State University Press, East Lansing, Mich. pp. 259-306.

Benjamin, D.M. 1998. Chinook salmon (Oncorhynchus tshawytscha) population dynamics in Lake Michigan, 19851996. M.Sc. thesis, Michigan State University, East Lansing.

Benjamin, D.M., and Bence, J.R. 2002. Statistical catch-at-age analysis of chinook salmon in Lake Michigan, 1985-1996. Fisheries Research Report, Fisheries Division, Michigan Department of Natural Resources, Ann Arbor.

Bennet, E.B. 1986. The nitrifying of Lake Superior. Ambio, 15: 272-275.

Brooks, A.S., and Torke, B.G. 1977. Vertical and seasonal distribution of chlorophyll $a$ in Lake Michigan. J. Fish. Res. Board Can. 34: 2280-2287.

Brown, E.H., Jr. 1972. Population biology of alewives, Alosa pseudoharengus, in Lake Michigan, 1949-70. J. Fish. Res. Board Can. 29: 477-500.

Chang, W.Y.B., and Rossman, R. 1988. Changes in the abundance of blue-green algae related to nutrient loadings in the nearshore zone of Lake Michigan. Hydrobiologia, 157: 271-278.

Clapp, D.F., Schneeberger, P.J., Jude, D.J., Madison, G., and Pistis, C. 2001. Monitoring round goby (Neogobius melanostomus) population expansion in eastern and northern Lake Michigan. J. Gt. Lakes Res. 27: 335-341.

Davis, B.M., Savino, J.F., and Ogilvie, L.M. 1997. Diets of forage fish in Lake Michigan. U.S. Environmental Protection Agency Report EPA/IAG DW14947692-01-0, Chicago, Ill.

DeVault, D.S., Hesselberg, R., Rodgers, P.W., and Feist, T.J. 1996. Contaminant trends in lake trout and walleye from the Laurentian Great Lakes. J. Gt. Lakes Res. 22: 884-895.

Doak, D.F., and Morris, W. 1999. Detecting population-level consequences of ongoing environmental change without long-term monitoring. Ecology, 80: 1537-1551.

Eck, G.W., and Brown, E.H., Jr. 1985. Lake Michigan's capacity to support lake trout (Salvelinus namaycush) and other salmonines: an estimate based on the status of prey populations in the 1970s. Can. J. Fish. Aquat. Sci. 42: 449-454.

Eck, G.W., and Wells, L. 1987. Recent changes in Lake Michigan's fish community and their probable causes, with emphasis on the role of the alewife (Alosa pseudoharengus). Can. J. Fish. Aquat. Sci. 44(Suppl. 2): 53-60.

Eshenroder, R.L., and Burnham-Curtis, M.K. 1999. Species succession and sustainability of the Great Lakes fish community. In Great Lakes fisheries and policy management: a binational perspective. Edited by W.W. Taylor and C.P. Ferreri. Michigan State University Press, East Lansing. pp. 145-184.

Evans, M.S. 1988. Toxic contaminants and ecosystem health: a Great Lakes focus. John Wiley \& Sons, New York.

Evans, M.S. 1992. Historic changes in Lake Michigan zooplankton community structure: the 1960 s revisited with implications for top-down control. Can. J. Fish. Aquat. Sci. 49: 1734-1749.

Evans, M.S., and Jude, D.J. 1986. Recent shifts in Daphnia community structure in southeastern Lake Michigan: a comparison of the inshore and offshore regions. Limnol. Oceanogr. 31: 56-67.

Fahnenstiel, G.L., and Scavia, D. 1987a. Dynamics of Lake Michigan phytoplankton: recent changes in surface and deep communities. Can. J. Fish. Aquat. Sci. 44: 509-514.

Fahnenstiel, G.L., and Scavia, D. 1987b. Dynamics of Lake Michi- 
gan phytoplankton: primary production and growth. Can. J. Fish. Aquat. Sci. 44: 499-508.

Fahnenstiel, G.L., and Scavia, D. 1987c. Dynamics of Lake Michigan phytoplankton: the deep chlorophyll layer. J. Gt. Lakes Res. 13: 285-295.

Fahnenstiel, G.L., Krause, A.E., McCormick, M.J., Carrick, H.J., and Schelske, C.L. 1998. The structure of the planktonic food-web in the St. Lawrence Great Lakes. J. Gt. Lakes Res. 24: 531-554.

Fitzsimons, J.D., Brown, S.B., Honeyfield, D.C., and Hnath, J.G. 1999. A review of early mortality syndrome (EMS) in Great Lakes salmonids: relationship with thiamine deficiency. Ambio, 28: 9-15.

Fratt, T.W., Coble, D.W., Copes, F., and Brusewitz, R.E. 1997. Diet of burbot in Green Bay and western Lake Michigan with comparison to other waters. J. Gt. Lakes Res. 23: 1-10.

Gardner, W.S., Nalepa, T.F., Frez, W.A., Cichocki, E.A., and Landrum, P.F. 1985. Seasonal patterns in lipid content of Lake Michigan macroinvertebrates. Can. J. Fish. Aquat. Sci. 42: 1827-1832.

Hatch, R.W., Haack, P.M., and Brown, E.H., Jr. 1981. Estimation of alewife biomass in Lake Michigan, 1967-1978. Trans. Am. Fish. Soc. 110: 575-584

Hay-Chmielewski, E.M., and Whelan, G.E. 1997. Lake sturgeon rehabilitation strategy.Special Report 18, Fisheries Division, Michigan Department of Natural Resources, Ann Arbor.

Holey, M.E., Rybicki, R.W., Eck, G.W., Brown, E.H., Jr., Marsden, J.E., Lavis, D.S., Toneys, M.L., Trudeau, T.N., and Horrall, R.M. 1995. Progress toward lake trout restoration in Lake Michigan. J. Gt. Lakes Res. 21(Suppl. 1): 128-151.

Hoyle, J.A., Schaner, T., Casselman, J., and Dermott, R. 1999. Changes in lake whitefish (Coregonus clupeaformis) stocks in eastern Lake Ontario following Dreissena mussel invasion. Gt. Lakes Res. Rev. 4(2): 5-10.

Janssen, J., and Jude, D.J. 2001. Recruitment failure of mottled sculpin Cottus bairdi in southern Lake Michigan, induced by the newly introduced round goby Neogobius melanostomus. J. Gt. Lakes Res. 27: 319-328.

Johengen, T.H., Johansson, O.E., Pernie, G.L., and Millard, E.S. 1994. Temporal and seasonal trends in nutrient dynamics and biomass measures in Lakes Michigan and Ontario in response to phosphorus control. Can. J. Fish. Aquat. Sci. 51: 2570-2578.

Jones, M.L., Koonce, J.F., and O'Gorman, R. 1993. Sustainability of hatchery-dependent salmonine fisheries in Lake Ontario: the conflict of predator demand and prey supply. Trans. Am. Fish. Soc. 122: 1019-1030.

Jude, D.J., and Tesar, F.J. 1985. Recent changes in the inshore forage fish of Lake Michigan. Can. J. Fish. Aquat. Sci. 42: 1154-1157.

Kabre, J.A. 1993. Impact of Renibacterium saloninarum on nonlipid energy, lipid and water contents in liver of infected chinook salmon during fall and spring in Lake Michigan, 1990-1992. Ph.D. thesis, Michigan State University, East Lansing.

Kitchell, J.F., and Carpenter, S.R. 1993. Cascading trophic interactions. In The trophic cascade in lakes. Edited by S.R. Carpenter and J.F. Kitchell. Cambridge University Press, New York. pp. 1-14.

Krause, A.E. 1999. Sampling variability of ten fish species and population dynamics of alewife (Alosa pseudoharengus) and bloater (Coregonus hoyi) in Lake Michigan. M.Sc. thesis, Michigan State University, East Lansing.

Krueger, C.C., Perkins, D.L., Mills, E.L., and Marsden, J.E. 1995. Predation by alewives on lake trout fry in Lake Ontario: role of an exotic species in preventing restoration of a native species. J. Gt. Lakes Res. 21(Suppl. 1): 458-469.

Kuhns, L.A., and Berg, M.B. 1999. Benthic invertebrate community responses to round goby (Neogobius melanostomus) and ze- bra mussel (Dreissena polymorpha) invasion in southern Lake Michigan. J. Gt. Lakes Res. 25: 910-917.

Lavis, D.S., Henson, M.P., Johnson, D.A., Koon, E.M., and Ollila, D.J. 2002. A case history of sea lamprey control in Lake Michigan: 1979-1999. J. Gt. Lakes Res. 28(Suppl. 1). In press.

Lehman, J.T. 1987. Palearctic predator invades North American Great Lakes. Oecologia, 74: 478-480.

Lehman, J.T., and Cáceres, C.A. 1993. Food web responses to species invasion by a predatory invertebrate: Bythotrephes in Lake Michigan. Limnol. Oceanogr. 38: 879-891.

Likens, G.E. (Editor). 1989. Preface. In Long-term studies in ecology-approaches and alternatives. Springer-Verlag, New York. pp. ix-xi.

Madenjian, C.P., and DeSorcie, T.J. 1999. Status of lake trout rehabilitation in the Northern Refuge of Lake Michigan. N. Am. J. Fish. Manag. 19: 658-669.

Madenjian, C.P., Jude, D.J., and Tesar, F.J. 1986. Intervention analysis of power plant impact on fish populations. Can. J. Fish. Aquat. Sci. 43: 819-829.

Madenjian, C.P., DeSorcie, T.J., and Stedman, R.M. 1998a. Ontogenic and spatial patterns in diet and growth of lake trout in Lake Michigan. Trans. Am. Fish. Soc. 127: 236-252.

Madenjian, C.P., Hesselberg, R.J., DeSorcie, T.J., Schmidt, L.J., Stedman, R.M., Quintal, R.T., Begnoche, L.J., and PassinoReader, D.R. 1998b. Estimate of net trophic transfer efficiency of PCBs to Lake Michigan lake trout from their prey. Environ. Sci. Technol. 32: 886-891.

Madenjian, C.P., Elliott, R.F., Schmidt, L.J., DeSorcie, T.J., Hesselberg, R.J., Quintal, R.T., Begnoche, L.J., Bouchard, P.M., and Holey, M.E. 1998c. Net trophic transfer efficiency of PCBs to Lake Michigan coho salmon from their prey. Environ. Sci. Technol. 32: 3063-3067.

Madenjian, C.P., Elliott, R.F., DeSorcie, T.J., Stedman, R.M., O'Connor, D.V., and Rottiers, D.V. 2000. Lipid concentrations in Lake Michigan fishes: seasonal, spatial, ontogenetic, and long-term trends. J. Gt. Lakes Res. 26: 427-444.

Magnuson, J.J., Meisner, J.D., and Hill, D.K. 1990. Potential changes in the thermal habitat of Great Lakes fish after global climate warming. Trans. Am. Fish. Soc. 119: 254-264.

Magnuson, J.J., Webster, K.E., Assel, R.A., Bowser, C.J., Dillon, P.J., Eaton, J.G., Evans, H.E., Fee, E.J., Hall, R.J., Mortsch, L.R., Schindler, D.W., and Quinn, F.H. 1997. Potential effects of climate changes on aquatic systems: Laurentian Great Lakes and Precambrian Shield Region. Hydrol. Process. 11: 825-871.

Makarewicz, J.C., Bertram, P., Lewis, T., and Brown, E.H., Jr. 1995. A decade of predatory control of zooplankton species composition of Lake Michigan. J. Gt. Lakes Res. 21: 620-640.

Makarewicz, J.C., Bertram, P., and Lewis, T.W. 1998. Changes in phytoplankton size-class abundance and species composition coinciding with changes in water chemistry and zooplankton community structure of Lake Michigan, 1983 to 1992. J. Gt. Lakes Res. 24: 637-657.

Makauskas, D., and Clapp, D. 2000. Status of yellow perch in Lake Michigan and Yellow Perch Task Group progress report. In Minutes of 2000 Annual Meeting of the Lake Michigan Committee. Great Lakes Fishery Commission, Ann Arbor, Mich.

McCormick, M.J. 1990. Potential changes in thermal structure and cycle of Lake Michigan due to global warming. Trans. Am. Fish. Soc. 119: 254-264.

McCormick, M.J., and Fahnenstiel, G.L. 1999. Recent climatic trends in nearshore water temperatures in the St. Lawrence Great Lakes. Limnol. Oceanogr. 44: 530-540. 
McQueen, D.J., Johannes, M.R.S., Post, J.R., Stewart, T.J., and Lean, D.R.S. 1989. Bottom-up and top-down impacts on freshwater pelagic community structure. Ecol. Monogr. 59: 289-309.

Nalepa, T.F. 1987. Long term changes in the macrobenthos of southern Lake Michigan. Can. J. Fish. Aquat. Sci. 44: 515-524.

Nalepa, T.F., Hartson, D.J., Fanslow, D.L., Lang, G.A., and Lozano, S.J. 1998. Declines in benthic macroinvertebrate populations in southern Lake Michigan, 1980-1993. Can. J. Fish. Aquat. Sci. 55: 2402-2413.

Nalepa, T.F., Fanslow, D.L., and Lang, G.A. 2000a. Trends in benthic macroinvertebrate populations in southern Lake Michigan over the past several decades. Internationale Vereinigung für Theoretische und Angewandte Limnologie Verhandlungen, 27: 2540-2545.

Nalepa, T.F., Hartson, D.J., Buchanan, J., Cavaletto, J.F., Lang, G.A., and Lozano, S.J. 2000b. Spatial variation in density, mean size, and physiological condition of the holarctic amphipod Diporeia spp. in Lake Michigan. Freshwater Biol. 43: 107-119.

Nalepa, T.F., Schloesser, D.W., Pothoven, S.A., Horndorp, D.W., Fanslow, D.L., Tuchman, M.L., and Fleischer, G.W. 2001. First finding of the amphipod Echinogammarus ischnus and the mussel Dreissena bugensis in Lake Michigan. J. Gt. Lakes Res. 27: 384-391.

Ney, J.J. 1990. Trophic economics in fisheries-assessment of demand-supply relationship between predator and prey. Rev. Aquat. Sci. 2: 55-81.

Nisbet, R.M. 1997. Delay differential equations for structured populations. In Structured population models in marine, terrestrial, and freshwater systems. Edited by $\mathrm{S}$. Tuljapurkar and $\mathrm{H}$. Caswell. Chapman and Hall, New York. pp. 89-118.

Pace, M.L., and Cole, J.J. 1989. What questions, systems, or phenomena warrant long-term study? In Long-term studies in ecology-approaches and alternatives. Edited by G.E. Likens. Springer-Verlag, New York. pp. 183-185.

Pekarik, C., and Weseloh, D.V. 1998. Organochlorine contaminants in herring gull eggs from the Great Lakes, 1974-1995: change point regression analysis and short-term regression. Environ. Monit. Assess. 53: 77-115.

Pothoven, S.A., Fahnenstiel, G.L., Vanderploeg, H.A., and Luttenton, M. 2000. Population dynamics of Mysis relicta in southeastern Lake Michigan, 1995-1998. J. Gt. Lakes Res. 26: 357-365.

Regier, H.A., Magnuson, J.J., and Coutant, C.C. 1990. Introduction to proceedings: symposium on effects of climate change on fish. Trans. Am. Fish. Soc. 119: 173-175.

Rutherford, E.S. 1997. Evaluation of natural reproduction, stocking rates, and fishing regulations for steelhead Oncorhynchus mykiss, chinook salmon $O$. tschawytscha, and coho salmon $O$. kisutch in Lake Michigan. Federal Aid in Sport Fish Restoration, Project F-35-R-22, Final Report. Michigan Department of Natural Resources, Ann Arbor, Mich.

Saether, O.A. 1980. The influence of eutrophication on deep lake benthic invertebrate communities. Prog. Water Technol. 12: 161-180.

Scavia, D., and Fahnenstiel, G.L. 1987. Dynamics of Lake Michigan phytoplankton: mechanisms controlling epilimnetic communities. J. Gt. Lakes Res. 13: 103-120.

Scavia, D., Fahnenstiel, G.L., Evans, M.S., Jude, D.J., and Lehman, J.T. 1986. Influence of salmonid predation and weather on long-term water quality trends in Lake Michigan. Can. J. Fish. Aquat. Sci. 43: 435-443.

Schelske, C.L. 1977. Trophic status and nutrient loading for Lake
Michigan. In North American project-a study of U.S. water bodies: a report for the Organization of Economic Cooperation and Development. Ecol. Res. Series, U.S. EPA, Rep. No. EPA600/3-77-086, Corvallis, Oreg.

Schelske, C.L., and Stoermer, E.F. 1971. Eutrophication, silica, and predicted changes in algal quality in Lake Michigan. Science (Washington, D.C.), 173: 423-424.

Schelske, C.L., Rothman, E.D., Stoermer, E.F., and Santiago, M.A. 1974. Responses of phosphorus limited Lake Michigan phytoplankton to factorial enrichments with nitrogen and phosphorus. Limnol. Oceanogr. 19: 409-419.

Schelske, C.L., Feldt, L.E., and Simmons, M.S. 1980. Phytoplankton and physical-chemical conditions in selected rivers and the coastal zone of Lake Michigan, 1972. Gt. Lakes Res. Div. Publ. No. 19. University of Michigan, Ann Arbor, Mich.

Schelske, C.L., Stoermer, E.F., Fahnenstiel, G.L., and Haibach, M. 1986. Phosphorus enrichment, silica limitation, and biogeochemical silica depletion in the Great Lakes. Can. J. Fish. Aquat. Sci. 43: 407-415.

Schneeberger, P.J. 2000. Population dynamics of contemporary yellow perch and walleye stocks in Michigan waters of Green Bay, Lake Michigan, 1988-96. Fisheries Research Report 2055, Michigan Department of Natural Resources, Ann Arbor, Mich.

Shroyer, S.M., and McComish, T.S. 2000. Relationship between alewife abundance and yellow perch recruitment in southern Lake Michigan. N. Am. J. Fish. Manag. 20: 220-225.

Stewart, D.J., and Ibarra, M. 1991. Predation and production by salmonine fishes in Lake Michigan, 1978-1988. Can. J. Fish. Aquat. Sci. 48: 909-922.

TeWinkel, L.M., Kroeff, T., Fleischer, G.W., and Toneys, M. 2002. Population dynamics of bloaters (Coregonus hoyi) in Lake Michigan, 1973-1998. In Biology and management of coregonid fishes-1999. Arch. Hydrobiol. Special Issues: Advances in Limnology, 57: 307-320.

Vollenweider, R. 1970. Scientific fundamentals of the eutrophication of lakes and flowing waters, with particular reference to nitrogen and phosphorus as factors responsible in eutrophication. OECD Publications, Paris.

Wells, L. 1970. Effects of alewife predation on zooplankton populations in Lake Michigan. Limnol. Oceanogr. 15: 556-565.

Wells, L. 1977. Changes in yellow perch (Perca flavescens) populations of Lake Michigan, 1954-75. J. Fish. Res. Board Can. 34: 1821-1829.

Wells, L., and McLain, A.L. 1972. Lake Michigan: effects of exploitation, introductions, and eutrophication on the salmonid community. J. Fish. Res. Board Can. 29: 889-898.

Wells, L., and McLain, A.L. 1973. Lake Michigan-man's effects on native fish stocks and other biota. Gt. Lakes Fish. Comm. Tech. Rep. No. 20.

Weseloh, D.V., Teeple, S.M., and Gilbertson, M. 1983. Doublecrested cormorants of the Great Lakes: egg-laying parameters, reproductive failure, and contaminant residues in eggs, Lake $\mathrm{Hu}-$ ron 1972-1973. Can. J. Zool. 61: 427-436.

Weseloh, D.V., Ewins, P.J., Struger, J., Mineau, P., Bishop, C.A., Postupalsky, S., and Ludwig, J.P. 1995. Double-crested cormorants of the Great Lakes: changes in population size, breeding distribution and reproductive output between 1913 and 1991. Colon. Waterbirds, 18(Spec. Publ. 1): 48-59.

Wesley, J.K. 1996. Age and growth of chinook salmon in Lake Michigan: verification, current analysis, and past trends. M.Sc. thesis, University of Michigan, Ann Arbor. 